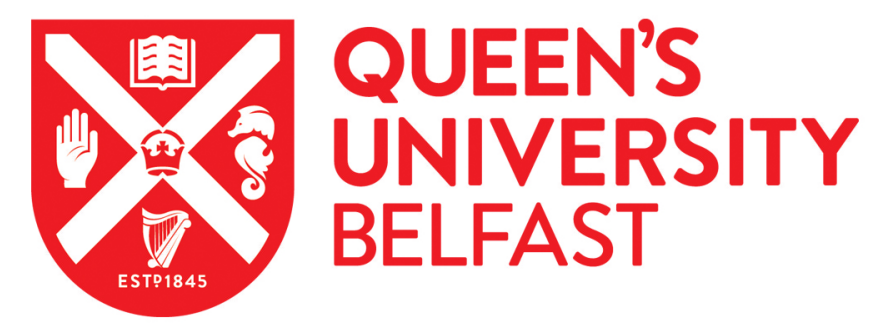

\title{
The Gift of the Gab in Post-Conquest Canterbury: Mystical 'Gibberish' in London, British Library, MS Cotton Caligula A. XV
}

Arthur, C. (2019). The Gift of the Gab in Post-Conquest Canterbury: Mystical 'Gibberish' in London, British Library, MS Cotton Caligula A. xv. Journal of English and Germanic Philology, 118(2), 177-210.

https://doi.org/10.5406/jenglgermphil.118.2.0177

Published in:

Journal of English and Germanic Philology

Document Version:

Peer reviewed version

Queen's University Belfast - Research Portal:

Link to publication record in Queen's University Belfast Research Portal

\footnotetext{
General rights

Copyright for the publications made accessible via the Queen's University Belfast Research Portal is retained by the author(s) and / or other copyright owners and it is a condition of accessing these publications that users recognise and abide by the legal requirements associated with these rights.
}

Take down policy

The Research Portal is Queen's institutional repository that provides access to Queen's research output. Every effort has been made to ensure that content in the Research Portal does not infringe any person's rights, or applicable UK laws. If you discover content in the Research Portal that you believe breaches copyright or violates any law, please contact openaccess@qub.ac.uk. 


\section{The Gift of the Gab in Post-Conquest Canterbury: Mystical "Gibberish" in $\underline{\text { London, British Library, MS Cotton Caligula A. xv }}$}

Many surviving ritual texts from early medieval England contain obscure letters, words, and phrases that are taken from different languages and alphabets. These rituals have been classified as "gibberish" in editions of Anglo-Saxon "charms", and they constitute a significant proportion of this corpus. The first comprehensive collection of "charms" was published in 1909 by Felix Grendon, who claimed that many rituals are characterized by their “incoherent jumbling of words, miscellaneously derived from Latin, Greek, Hebrew, Gaelic, and other tongues". ${ }^{1}$ Grendon believed that these seemingly meaningless words reflect the corrupt copying of classical sources that were used in specifically English contexts, and he therefore created a large sub-category of "gibberish charms", which he described as follows:

\footnotetext{
"These conjurations, unlike the preceding ones, are crude, formless pieces, destitute of literary merit. Their distinguishing feature is a meaningless formula composed of a jumble of more or less obscure words. Occasionally a Greek, Latin, Hebrew, Gaelic, or Anglo-Saxon word appears, and a few words seem to have had their origin in one or other of those languages; but the derivation of a majority of the words is not ascertainable... [in some charms] the formula consists, not of meaningless words strung together, but of unintelligible collocations of liturgical Latin. As a rule, the ceremonies prescribed are of Heathen ancestry". ${ }^{2}$
}

According to Grendon, Anglo-Saxon scribes used foreign languages associated with Christian writings to adapt rituals that were heathen in origin. 
The second principal collection of Anglo-Saxon "charms" was published in 1948 by Godfrid Storms, and he classified twenty-one out of eighty-six texts as "gibberish". ${ }^{3}$ Storms argued that foreign languages and alphabets were appealing to Christian scribes who erroneously copied down exotic formulas:

\footnotetext{
"The Anglo-Saxons borrowed from diverse sources, Greek, Irish, Hebrew and especially Latin, and a number of charm formulas evidently owe their effect to the mystification of a foreign tongue... This and the next twenty formulas may be called 'gibberish or jingle charms', because the contents have become incomprehensible for the most part. The reason lies in the introduction of foreign elements whose meaning soon became unknown, with the result that the words gradually developed into unintelligible, meaningless sounds". ${ }^{4}$
}

Storms believed that the obscure words and letters of these rituals arose out of the scribes' misunderstanding of source materials, and that they were erroneously copied because their foreign sounds and epigraphic appearance were appealing.

Similar arguments have been made in recent scholarship. For example, Paul Cavill, (among many others) thinks that "gibberish" writing, "magical gobbledegook", and "mumbojumbo" reflect a "literature of desperation" that was used by Christian scribes to replace heathen formulas with mysterious sounding foreign languages to console superstitious patients. ${ }^{5}$ However, Karen Jolly and Leslie Arnovick have argued that words did not have to be understood to be efficacious in medieval texts; the more mysterious an exotic word sounds, the more successful it would be in communicating with the spiritual world. ${ }^{6}$ Importantly, these approaches credit scribes and compilers with logical reasons for including such enigmatic texts in manuscripts that were written in high-status minsters. However, they 
maintain that obscure writing represents a language that was only understood by spirits and that mystified Anglo-Saxon audiences, neither of which can be proven. This article argues that some obscure rituals may instead reflect efforts to censor powerful texts that could only be performed by those who knew how to read and decipher them. In some cases, there is evidence to suggest that scribes turned to different sources that were available in their monastic libraries and used archaic or exotic content to deliberately obfuscate the meaning of the texts they were writing. In other words, "gibberish" writing may reflect more about the composers, copyists, or authorised performers of these rituals than it does about the effects it had on human and spiritual audiences.

One manuscript that was written in a major ecclesiastical centre in early medieval England provides important evidence to suggest that highly educated ecclesiastics, who had knowledge of multiple languages, may have at least known of some of these texts, if they did not also have need to use them. The so-called "gibberish" rituals of London, British Library, MS Cotton Caligula A. xv (+ MS Egerton 3314) are directly informed by other materials in the manuscript collection, which contains interesting details about the political environment of Canterbury in the decade after the Norman Conquest and a legend about a saint who received instruction from an angel in a mystical language. When read as a whole, this manuscript collection challenges notions of "gibberish" writing and offers fascinating insight into an immediate historical context in which these texts may have been used, or indeed for which they may have been written. Its close textual correspondences with other contemporary manuscripts that contain ciphers, foreign alphabets, and hermeneutic vocabulary may also indicate that its obscure rituals draw upon wider intellectual strategies of textual concealment from the early medieval period. 
London, BL, Cotton Caligula A. xv (fols. 120-141) forms Part A of an originally larger manuscript that included BL, Egerton 3314 (fols. 9-72). The original collection was separated sometime after 1185, when a monk and sub-prior called Salomon from Christ Church cathedral made additions to both manuscripts. ${ }^{7}$ The original manuscript (Caligula A. xv + Egerton 3314) was written by a single Anglo-Saxon scribe and it included computistical calculations, prognostications, calendars, annals of Christ Church cathedral, "charm" rituals (Caligula A. xv), and astronomical texts attributed to Bede, Isidore, and Hrabanus Maurus (Egerton 3314). ${ }^{8}$ The annals indicate a terminus ante quem date of 1073 for the first stage of writing as the original scribe's hand is evident in entries up to this year, although a further entry was added by the same scribe in a different ink for the year $1076 .{ }^{9}$ More texts were added to the original collection in the late eleventh or early twelfth century, including extracts from Ælfric's De temporibus anni, and a number of later scribes continued the annals to the year 1268. For the ensuing argument, I will refer to the Caligula A. xv manuscript but it is worth bearing in mind that Egerton 3314 (containing further astronomical texts) was also originally part of the collection at the time of writing.

The order of appearance of texts in what is now Caligula A. Xv is as follows (all texts are written by the main scribal hand unless otherwise indicated):

120r-127r: Easter tables and computus.

122v-123r: Illustration of St Pachomius receiving the None Aprilis rule for calculating Easter from an angel from heaven (122v). Immediately to the right (123r) is an illustration of Christ surrounded by angels, one of whom receives the Easter calculation from Christ's right hand. These illustrations are immediately above a None Aprilis Easter table. 
123v-124r: A runic inscription runs along the bottom of the two folios in a similar ink to the main scribal hand. ${ }^{10}$ It is written below another table with lunar letters. $125 \mathrm{v}$ : Sphere of Apuleius with the Collige per numeros poem written above. ${ }^{11}$ 125v-129r: Days of the lunar month; medical lunarium; notes on computus in English and Latin.

129r: "Gibberish" ritual against fever (Wið gedrif); two Latin rituals against pox (Wið poccas) and swellings (Wið geswell).

130v-132r: Further notes on the lunar cycle; lunar charts and prognostics; a rule for calculating the date of Easter in English; prohibitions against blood-letting; notes on computus and beneficial days for childbirth; a dream lunarium and a birth lunarium. 132v-135r: Easter table with annals of Christ Church, Canterbury. The first entry is written above the table on $133 \mathrm{r}$ for the year 925 . The first entry in the table is for the year 988 and continues to the year 1073, with an additional entry for 1076 added in a different ink by the main scribe.

135r-138v: Continuations of annals of Christ Church up to the year 1193 in a variety of later hands.

138v-139r: Originally blank pages, presumably left blank for continued annal entries. Further annals for the years 1194-1268 in two later hands.

139v: Notes on the six ages of the world. Further notes on the ages of Mary and Christ when they died, how many years Adam was in Hell, and how many peoples descended from Noah's sons.

140r: The Heavenly Letter ritual containing "gibberish"; a "gibberish charm" to obtain favors from one's lord or king.

140v-141r: Dialogue between Saints Jerome and Damasus on the proper times to celebrate Mass; notes on the days of the moon and lengths of seasons. 
The original scribe and compiler seem to have viewed the "gibberish" rituals as appropriate for a collection of texts concerned with spiritual and temporal matters.

Upon first impressions, the rituals may seem to be out of place in a collection of texts that focus on astronomy, computus, and the history of Canterbury cathedral but connections can be found between these various materials. The rituals have correspondences with the surrounding texts that are associated with Church Fathers, and the illustration spanning folios $122 \mathrm{v}-123 \mathrm{r}$ relates a story about how St Pachomius received the correct calculation of Easter in a mystical language, providing a context for their obscure writing. The collection also reflects an interest in contemporary events at Christ Church cathedral through its inclusion of annals (132v-139r) and a ritual to influence the king and other superiors (140r).

The spiritual and temporal texts that surround the "gibberish" rituals inform us of the intellectual environment in which they were written, and they provide an historical context for the use of obscure language in a high-status minster at Canterbury. Furthermore, as the manuscript was first written around 1073 in Christ Church cathedral, it may have been written for a high-ranking ecclesiastic. In 1070 Lanfranc came to Christ Church and was appointed as Archbishop of Canterbury, as recorded in the annals of this manuscript (fol. 135r): “mlxx [1070]. On pison geare com landfranc abbod 7 hine man halgode to bisceope to xpes (Cristes) cyrce". ${ }^{12}$ The annals focus heavily on the appointments and activities of Archbishops of Canterbury, and a list of archbishops was later added in the late eleventh or early twelfth century. ${ }^{13}$ These may also indicate that the manuscript was originally written for an archbishop's use.

Scholars have understood the collection in Caligula A. Xv as a composite of different units, and they have separated groups of texts from their wider manuscript context according to their "scientific" and astronomical content. Other materials, however, are often described 
as evidence of popular superstition. Stephanie Hollis, for example, argued that collections like Caligula A. xv reveal the diversity of English monastic interests as they contain both scientific and superstitious texts, and that their less scientific content reflects the decline of intellectual standards of monasteries on the eve of the Conquest. ${ }^{14}$ Karen Jolly included Caligula A. Xv in a category of manuscripts that she called "natural science and service books". ${ }^{15}$ She also discussed three rituals from this manuscript that are classified as "gibberish" in printed editions of charms, arguing that they may utilise cruciform shapes and liturgical formulas in ways that correspond to the collection's overall thematic focus on Christian cosmology. ${ }^{16}$ In their respective studies of Anglo-Saxon prognostics, Lázló Sándor Chardonnens and Roy Liuzza observe that these texts are not grouped together according to genre in the manuscript witnesses, perhaps reflecting the individual interests of original compilers. ${ }^{17}$ Liuzza, however, also says that their appearance in manuscripts - including Caligula A. xv - seems to mark a point of intersection between medicine and computus. ${ }^{18}$

Caligula A. Xv has often been perceived as a miscellaneous collection, and its prognostications and rituals have been interpreted as superstitious customs and magical pagan cures that were intermingled with mainstream Christian texts and "scientific" materials. In more recent times, some scholars have argued that the collection is more homogeneous but still maintain that there are distinctions between different units or genres within this manuscript, and the rituals are often separated as unrelated "gibberish" texts. I argue that the collection is even more coherent than scholars have proposed, and that contemporaries would not have seen the "gibberish" materials as being pagan or superstitious at all. When these texts are discussed in their wider manuscript context, we may better understand how the scribe or compiler perceived them as mystical Christian rituals, how they appear to have close correspondences with contemporary hermeneutic styles at Canterbury, and how they 
were important components of the collection as a whole, which was not organised in an arbitrary manner. ${ }^{19}$

\section{THE “GIBBERISH” RITUALS OF CALIGULA A. XV}

Various strategies of textual concealment can be found in other manuscripts with close textual correspondences with Caligula A. xv. For example, the Vitellius Psalter $(1060 \times$ 1087, New Minster, Winchester) uses unconventional abbreviations in its glossed psalms and rituals, and it also contains a guide to the encryption of texts. ${ }^{20}$ Alfwine's Prayerbook (1023 $\times 1031$, New Minster, Winchester) also contains ciphers and rituals with obscure letters from different alphabets. ${ }^{21}$ The Sphere of Apuleius that is found on fol. $125 \mathrm{v}$ of Caligula A. xv uses Greek letters, and in Oxford, St John's College, MS 17 (c. 1110, Thorney Abbey) Greek letters are used with cryptographic writing in a Sphere of Petosiris (fol. 8r). ${ }^{22}$ St John's College 17 also contains further cryptograms and a table with the Roman, Greek, Hebrew, and runic alphabets recorded side by side, with numerical values that could be substituted for each letter. Varying techniques of textual concealment and letter substitution reflect contemporary monastic interests in obscurity, and they provide a more convincing context in which to understand the enigmatic materials of Caligula A. xv than dismissing them as the nonsensical result of scribal error. Furthermore, the obscure passages contain rare words or phrases that are also found in glossed psalters, late-antique texts, and hermeneutic writings from Canterbury, indicating that these kinds of sources were used when the rituals were composed or deliberately obfuscated during the copying process. A reinterpretation of the "gibberish" materials in Caligula A. xv has not been taken far enough in light of these techniques and interests in obscurity, so let us begin by considering the texts in question.

On folio 129r, a series of three rituals are written immediately after a lunar calculation with a blank line separating the texts. The first ritual for fever (Wið gedrif) was written by the 
original Anglo-Saxon scribe in a brown ink that is different to the black ink used for the preceding texts. A transcription of this ritual reads:

Wið gedrif. + In nomine domini nostri ihu xpi [Iesu Christi]. tera. tera. tera. testis. I contera. taberna. gise. ges. mande. leis. bois. eis. andies. mandies. / moab. lib. lebes. Dominus deus adiutor sit illi. illi. eax. filiax. artifex. amen. ${ }^{23}$

This passage is very hard to translate, though there are some clearly decipherable words. The Old English title is followed by a Latin invocation of Christ that opens the ritual ("In the name of our Lord Jesus Christ"). The text is also framed by a cross-marker at the beginning and amen at the end, thus presenting it as a prayer. Indeed, the petition "Dominus deus adiutor sit illi" ("May the Lord God be a helper for him") appears towards the end of the passage and seems to follow from the opening invocation.

The words that are written between these Latin phrases are, however, more obscure. Alliteration plays an important role in the grouping of words, probably for oral effect, as seen in the triple repetition of tera and the proceeding testis ('witness') and taberna (possibly an abbreviation for tabernacula, 'tabernacle'). The words gise and ges clearly alliterate as well, and there may be some (possibly anagrammatic) significance in their similar spelling. The words "mande leis bois eis" are difficult to interpret but mande may be the present imperative singular form of the verb mandere ('to eat / devour'), leis may be the dative / ablative plural form of the adjective leus ('smooth'), and bois may be the dative / ablative plural form of the noun boa, which Pliny the Elder describes as both a large Italian serpent and a disease causing smallpox. ${ }^{24}$ Significantly, this text is followed by a ritual for smallpox ("uariolam"), indicating that it draws upon Pliny or similar late-antique sources. If the identification of 
these words is correct, this passage seems to be a command to devour the sufferer's smallpox, suggesting that this ritual also works against this disease.

The words "moab lib lebes" that follow in this passage appear to be an obscure reference to Psalm 107. In the Gallican and Hebraicum version of this psalm, verse 10 reads "moab lebes spei meę" ("Moab is my washpot"), and the word lebes ("washpot') follows the reference to Moab in this ritual. ${ }^{25}$ The relevance of this psalm to a ritual against fever may be found in its petition to God to deliver His people and triumph over their enemies:

ut liberentur dilecti tui. Saluum do dextera tua et exaudi me... Da nobis auxilium de tribulatione qui $a$ uana salus hominis. In deo faciemus uirtutem et ipse ad nichilum deducet inimicos nostros. ${ }^{26}$

(that your beloved may be delivered. Save with your right hand and hear me... Give us help from trouble, for vain is the help of man. In God we shall do bravely, and He will bring our enemies to nothing).

The few words that are taken from this psalm may indicate that it is to be sung in its entirety, as is the case with other texts containing psalm incipits. It seems likely that, rather than providing evidence of garbled and misunderstood source materials, this obscure passage encodes relevant references from Scripture and perhaps at least one late-antique source to counteract the harmful forces causing fever. The final Latin petition is followed by "eax. filiax. artifex", which are clearly linked by their assonating ' $x$ ' endings. The only identifiable noun is artifex ('author', 'creator'), whereas the previous two words may simply be $e a$ ('he / she / it') and filia ('daughter') with an additional ' $\mathrm{x}$ ' ending to add to the oral effect. It seems possible that these final words are an invocation of the Creator to aid the sufferer, although 
their grammatical forms may have been deliberately altered, in similar fashion to other hermeneutic techniques employed in texts from Canterbury. ${ }^{27}$

Karen Jolly believes that this passage may have been rearranged into a cruciform layout so that it could be used as an amulet. ${ }^{28}$ However, the cross-marker, the Latin invocation, the use of alliteration and assonance, and the concluding amen suggest that it was to be vocalised. The similarities and variations in some of the words - such as gise and ges, andies and mandies, tera and contera - perhaps provide clues for how to read the passage. As some words and references are decipherable, it may be the case that these words are obscured or encrypted in some way and that a skilled reader could have known how to decipher them.

Two other rituals for pox and swellings immediately follow this text, and Thomas Oswald Cockayne included these in his collection of Anglo-Saxon "charms". ${ }^{29}$ Scholars, however, do not usually associate these texts with the preceding ritual against fever because they do not contain "gibberish" formulas. These texts read:

Wið poccas. Sanctus nicasius habuit minutam uariolam \& rogauit dominum / ut quicumque nomen suum secum portare scriptum. / Sancte nicasi presul \& martir egregie ora pro me $\mathrm{N}$ peccatore \& ab hoc / morbo tua intercessione me defende. amen. /

Wið geswell. Domine ihu xpe [Iesu Christe] deus noster per orationem serui tui blasii festina / in adiutorium meum.

(Against pox. Saint Nicasius had a little smallpox and asked the Lord that whoever has written his name should carry it with him: Saint Nicasius, eminent protector and martyr, pray for me [Name], sinner, and from this sickness defend me by your intercession. Amen. 
Against swelling. Lord Jesus Christ our God, through the prayer of your servant Blaise, hasten to my aid).

The first of these two rituals for pox invokes Saint Nicasius, Bishop of Rheims (d. circa 407), who according to legend suffered from smallpox. ${ }^{30}$ The short opening narrative about Nicasius claims that those who carry the saint's name will be protected from the illness, suggesting that the ensuing prayer should be written down and carried on the person. The ritual against swelling is the final entry on folio $129 \mathrm{r}$ and it completes this short series of healing texts. The connection between these three rituals is clear as smallpox causes fever and lesions in the skin that can form blisters and swellings. ${ }^{31}$ As noted above, the word bois in the first ritual may also be a reference to a disease causing smallpox, thus providing a direct semantic link between these texts. Like the two preceding rituals, this one has an Old English title and opens with a Latin invocation, which is a simple petition to Christ through the intercession of Saint Blaise that the sufferer may be delivered from the swelling. The petition shares similarities with the preceding sequence in the ritual for fever in its invocation of Christ for help.

The texts for pox and swelling invoke the intercession of two Church Fathers (Saints Nicasius and Blaise), and other Anglo-Saxon rituals for fever invoke the Seven Sleepers, the four evangelists, Mary, the angels, cherubim, seraphim, and the Trinity, indicating that these texts were inspired by biblical and apocryphal sources. ${ }^{32}$ The close thematic connections between these three rituals on folio 129r strongly suggest that the Anglo-Saxon scribe did not make distinctions between them, and that the "gibberish" of the fever ritual was understood to be as powerful as the other Latin invocations against sickness. Indeed, it might have been perceived to be more powerful than the readable Latin prayers, and may thus have been deliberately obscured, possibly through anagrammatic writing. 
There are two further rituals in this collection that have been categorised as "gibberish charms" by editors. ${ }^{33}$ The Heavenly Letter and a ritual to obtain favors appear together towards the end of the original collection on folio 140r, and these texts use obscure language to address sickness and political concerns. ${ }^{34}$ The Heavenly Letter opens with a statement that it was brought to St Peter's altar in Rome by an angel from heaven, and it outlines the different benefits that it brings when it is recited. A lengthy passage of obscure Latin then follows this introduction. The full text reads:

Se engel brohte pis gewrit of heofonum. 7 lede hit on uppan pes petrus / weofud on rome. Se pe pis gebed singð on cyrcean ponne forstent / hit him sealtera sealma. And se pe hit singð æt his ende dæge / ponne forstent hit him husel gang. And hit mæg eac wið / æghwilcum uncupum yfele ægðer gefleogendes gefarendes. / Gif hit innon bið sing pis on wæter syle him drincan. sona / him bið sel. Gif hit ponne utan si sing hit on fersce buteran. / 7 smere mid pat lic. sona him kymð bot. And sing pis ylce ge/bed on niht ær pu to pinum reste ga. ponne ge scylt pe god / wið unswefnum pe nihternessum on menn becumað. /

Matheus. Marcus. Lucas. Iohannes. bonus fuit \& sobrius religiosus. / me abdicamus. me parionus. me orgillus. me ossius ossi dei / fucanus susdispensator \& pisticus. / M. M. L. I. Cum patriarchis fidelis. Cum prophetis et herilis. / Cum apostolis humilis. IHU XPI [Ihesu Christi] \& matheus cum sanctis de [read ac] fidelibus / adiunctus. est. actibus. /

M. M. L. I. Deum patrem. Deum filium. Deum spiritum sanctum trinum / \& unum \& iohannem basileus fidelium damasci per suffragium / sancti spiritus lucidum omnipotens uirtutibus sanctus. est. in sermonibus. / 
M. M. L. Iohannes. Panpulo dimisit \& addi netum . $\Lambda$. \& . . per / camellos ab iunctionibus degestum sit pro omni dolore / cum dubitu obseruatione obseruator. Exultabunt sancti in / gloria. Letabuntur [in cubilibus suis]. Exultationes dei in faucibus eorum. \& gladii. / Laudate dominum in sanctis eius. oð ende.

(The angel brought this letter from heaven and laid it upon St Peter's altar in Rome. He who sings this prayer in church, then it will benefit him as the psalms of the psalter. And he who sings it on his last day [i.e. on his deathbed], then it will benefit him as much as [receiving] the Eucharist. And it can also [be used] against every unknown evil, both flying and faring. If it is internal, sing this over water, give him to drink. He will soon be well. If it is external, sing it over fresh butter and anoint the body with it. He will soon come to health. And sing this same prayer at night before you go to your bed; then God will shield you against bad dreams and nightmares that come upon men:

"Matthew, Mark, Luke, John. He was a good and sober, religious [man]. Not lawless

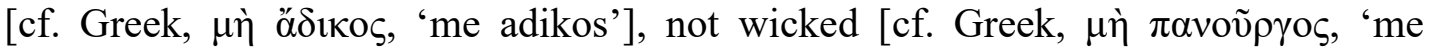

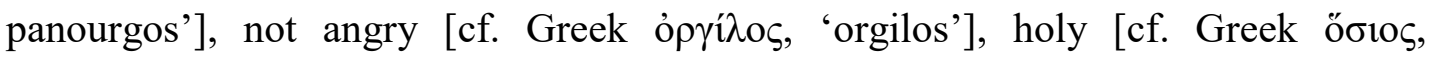

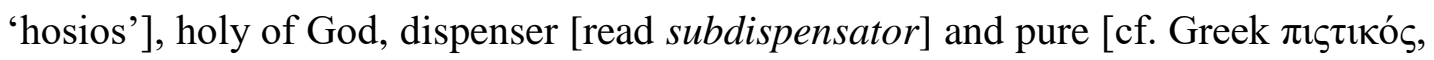
'pistikos'].

Matthew, Mark, Luke, John. With the faithful Patriarchs. With the Prophets and masters. With the humble Apostles. Jesus Christ and Matthew with the saints and faithful are joined good works. Matthew, Mark, Luke, John. God the Father, God the Son, God the Holy Spirit, triune and one, and John, Basil, faithful of Damasus, through the bright judgement of the omnipotent Holy Spirit. The Spirit is in powerful words. 
Matthew, Mark, Luke, John. Panpulo sent forth and unified Netum [a Sicilian city,

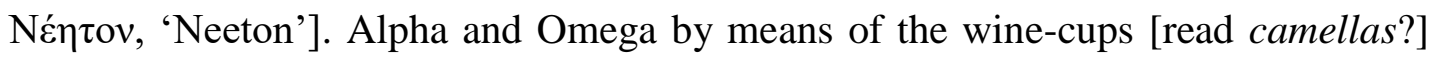
with anointing may all pain with doubt be carried away in heeding this observation. Let the faithful rejoice in glory. Let them rejoice [on their couches]. Let the praises of God be in their throats [Psalm 149]. Praise the Lord in his holy place [Psalm 150], until the end").

Other apotropaic texts that claim to have been transmitted from heaven by an angel testify to a more widespread tradition dating from the fourth century. ${ }^{35}$ However, the Old English instructions of this text are unique as they state that reciting this ritual can be as effective as praying the psalter and receiving the Eucharist. Given that the manuscript was produced in Christ Church, this ritual's ability to substitute the psalms of the psalter would have obvious benefits to monks and clerics under the obligation of praying the Divine Office. If the performer were intended to be a lay person, then it may have encouraged lay devotions which were presented as equivalents to monastic prayer. ${ }^{36}$

The ritual's claim that its recital on the death-bed has the same effect as receiving the Eucharist is more remarkable ("se pe hit singð æt his ende dæge / ponne forstent hit him husel gang"). There are many Anglo-Saxon rituals that prescribe the use of the Eucharist with other ritual actions and utterances, some of which demonstrate close correspondences with liturgical ordines for anointing the sick at the death-bed ${ }^{37}$ The association of this ritual with the Last Rites is perhaps reflected in the instruction to anoint the body if the sickness is external ("Gif hit ponne utan... smere mid pat lic"). However, to my knowledge no other Anglo-Saxon ritual claims to be as powerful as receiving the Eucharist. This statement suggests that if a sick person could not receive the Eucharist in the administration of Extreme Unction, then in cases of emergency the singing of these divine words could have sufficed 
instead. The ritual was also believed to be effective against all unknown evil, nightmares, and internal and external sickness.

The passage that follows these instructions consists of prayers that invoke the four evangelists. The first prayer is the most difficult to interpret, and it is possibly taken from a hagiographical source as it refers to somebody who had saintly qualities in being good, sober, and religious ("bonus fuit \& sobrius religiosus"). ${ }^{38}$ The Dictionary of Medieval Latin for British Sources suggests that the ensuing phrases are taken from Greek, and if this is the case then their corrupted forms may reflect the scribe's phonetic pronunciation of these words

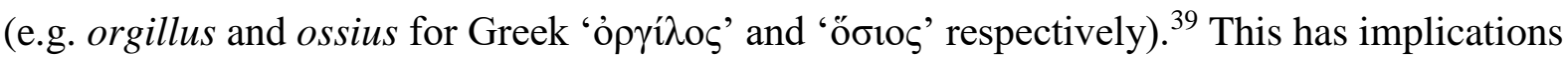
for the use of Greek at Christ Church cathedral, and even if knowledge of this language was not comprehensive, there seems to be an attempt to engage with it in this ritual text. Further evidence for Greek writing in Canterbury at this time may be found in the so-called "Cambridge Songs" manuscript (Cambridge, University Library, MS Gg. 5. 35; c. 1050, St Augustine's, Canterbury), which contains liturgical prayers in Greek as well as a Greek alphabet and extensive grecisms. ${ }^{40}$

The "Cambridge Songs" manuscript is known for its density of hermeneutic materials that were used in the monastic curriculum. Michael Lapidge has demonstrated that Oda of Canterbury (archbishop 941-958) was also a strong proponent of the hermeneutic style, and that his pupil Frithegod produced the most ostentatious hermeneutic text of the period. ${ }^{41}$ Frithegod's Breuiloqium Vitae Wilfredi (written in 947) contains extensive archaisms, grecisms, Hebraisms, and neologisms, and there is an indication that similar hermeneutic vocabulary is employed in the Heavenly Letter. ${ }^{42}$ The words "pisticus" (at the end of the ritual's first passage) and "basileus" (in the third prayer) both appear in Frithegod's Vitae Wilfredi. Interestingly, "basileus" was used as a synonym for "rex" ("king") in Anglo-Saxon and Carolingian glosses but "pisticus" is much rarer, and the appearance of both together may 
suggest that the scribe consulted a copy of Frithegod's work in the cathedral for its wealth of hermeneutic vocabulary (perhaps London, British Library, MS Cotton Claudius A. i, fols. 5r36v; c. 950, Christ Church, Canterbury). ${ }^{43}$ "Pisticum" is used in John's gospel to describe the pure, sweet-smelling oil ("nardum") that is used to anoint Christ's feet (cf. John 12. 3), and it is worth noting that in the instructions to this ritual provision is made for anointing the body. The word also appears in Isidore's Etymologies (Book xvii, 7. 30), the so-called Leiden Glossary (Leiden, University Library, Voss. Lat. Q. 69), and a glossary in Cambridge, Corpus Christi College, MS 144. ${ }^{44}$ The Leiden Glossary was copied in St Gall around 800 from an earlier glossary that originated in the school of Theodore and Hadrian in Canterbury between 670 and $690 .{ }^{45}$ Corpus 144 was also written in St Augustine's, Canterbury in the eighth century, and it also contains a text on interpretations of Hebrew and Greek names. ${ }^{46}$ It may therefore be possible that the scribe of the Heavenly Letter had access to a similar glossary (perhaps a Latin-Greek one) in the cathedral that contained entries for both "pisticus" and "basileus", if he was not working directly with Frithegod. The ritual uses obscure vocabulary in its first prayer to describe the renunciation of vices and the affirmation of virtues and purity, possibly in reference the good, sober, and religious person implied in the first phrase.

The next Latin prayers are less obscure, and they all begin by invoking the evangelists in the same way as the first prayer. The focus of the second prayer is on the hierarchy of heaven, as it invokes the Patriarchs ("patriarchis"), prophets ("prophetis"), apostles ("apostolis", "matheus"), Christ (IHU XPI), and the saints ("cum sanctis"). The third prayer opens with an invocation of the Trinity before calling upon a certain John, probably the evangelist. The word "basileus" appears immediately after and it could either mean "royal" (being synonymous with "rex") or it could denote St Basil ("Basilius", d. 379), who was a faithful companion of St Damasus (“fidelium damasci”, Pope from 366-384). I have favored 
the latter possibility in my tentative translation because a reference to Basil would make perfect sense here; the Church Fathers who are singled out were contemporaries of Saints Jerome, Pachomius, and Nicasius, and all of these are mentioned elsewhere in the manuscript collection.

The final part of this prayer seems to focus on the power of speech through the Holy Spirit ("per suffragium / sancti spiritus lucidum omnipotens uirtutibus sanctus. est. in sermonibus"). Despite the obscurity of this prayer, there is an evident connection between the Church Fathers, the Holy Spirit, and powerful words. The fourth and final prayer of the Heavenly Letter begins with a reference to a certain legend concerning an unidentifiable Panpulo, possibly an angel, who was sent out to the Sicilian city of Netum ("Panpulo dimisit \& addi netum"). Christ's title as Alpha and Omega (cf. Rev. I.8, XXII.13) is then marked in Greek letters before an obscure petition is made to relieve the subject from pain and doubt ("pro omni dolore cum dubitu"). The sufferer is to be relieved through anointing ("ab iunctionibus"), reflecting the opening vernacular instructions and possibly the reference to "pisticus". The prayer concludes with quotations from Psalm 149 ("Exultabunt sancti in gloria. Letabuntur [in cubilibus suis]. Exultationes dei in faucibus eorum. \& gladii”) and Psalm 150 ("Laudate dominum in sanctis eius"), which are to be sung in full ("oð ende"). Verses 5-6 of Psalm 149 that describe the faithful singing for joy on their couches correspond with the opening instructions to recite this text every night in bed ("sing pis ylce ge/bed on niht ær pu to pinum reste ga") or if the subject is sick and presumably bedridden. The first verse of Psalm 150 that declares praise of God in His sanctuary likewise corresponds with the opening instruction to recite this ritual inside the church building ("Se pe pis gebed singð on cyrcean"). These particular psalm references are carefully chosen for their relevance to this ritual. 
The passage of the Heavenly Letter that is to be sung is very obscure in many places. It could perhaps have been written or copied by a scribe with a poor command of Latin, though this is unlikely given that it was written at Christ Church at a time when many competent scribes were working. The scribe of Caligula A. Xv also may have copied this text very literally without paying much attention to the apparent errors. However, the text's claim to a divine origin and equivalence with the Eucharist, in addition to the scribe's competency in Latin from the evidence of other texts in the collection, do not support this conclusion. Furthermore, some obscure words are found both in this text and in Frithegod's Breuiloqium Vitae Wilfredi, which was also written in Canterbury Cathedral. The Heavenly Letter's use of grecisms and possible neologisms follows hermeneutic styles that were known at this highstatus minster in the tenth and eleventh centuries. It may be the case that the scribe consulted Frithegod, a Latin-Greek glossary, and a glossed psalter at the time of writing, perhaps in an attempt to deliberately obscure the ritual's meaning; the close familiarity with psalter glosses was also seen in the previous ritual against fever. If, on the other hand, the text was copied from an earlier composition that followed hermeneutic techniques, the scribe may have perceived it as a sacred ritual that was indeed transmitted from heaven by an angel, and therefore in no need of correction. Patristic writers like Isidore and Anglo-Saxon ecclesiastics like Ælfric maintained that God is beyond the rules of grammar, and it may not have been surprising for a text to be obscure and grammatically confusing if it had a heavenly origin. ${ }^{47}$ Indeed, Isidore claimed that Scripture is deliberately obscure to conceal its divine meaning and encourage spiritual discernment:

Ideo in libris sanctis quaedam obscura, quaedam aperta reperiuntur, ut intellectus lectoris et studium augeatur. Nam si cuncta paterent, statim intellecta vilescerent. ${ }^{48}$ 
[Some things in Holy Scripture are clear, others obscure, in order to increase the understanding and diligence of the reader. For if everything were immediately comprehensible, it would be cheapened]. ${ }^{49}$

The Heavenly Letter has demonstrable connections with other materials in the collection which strongly indicate that the scribe perceived it as a ritual with obscure, mystical words of power.

The final so-called "gibberish" text in Caligula A. xv appears immediately after the Heavenly Letter and is a ritual to obtain favors from one's lord, king, or council. This ritual is unique as there is no other surviving text that bears any resemblance to its claims or content. This ritual appears at the bottom of folio 140r and is followed overleaf by a text on the correct celebration of Mass in the form of a dialogue between Saints Jerome and Damasus. The ritual is fragmentary in places due to erasures, and a transcription is as follows:

Gif pu wille ga [...] pinum hlaforde oppe to kyninge / oppe to oprum menn oððe to gemote ponne bær pu pas / stafas [ ]lc pæ[ ] ponne bið h[ ] b[ ] lipa bli[ ] x x [ ] h .d.e.o.e. / o.o.e.e.e.laf.d.R.U.fi.ð.f.p.A.x.Box.Nux. In nomine / patris Rex.M.per.X.xix.xcs.xћ.iћ. + Deo.eo.deo.deeo. / Lafdruel.bepax.box.nux.bu. In

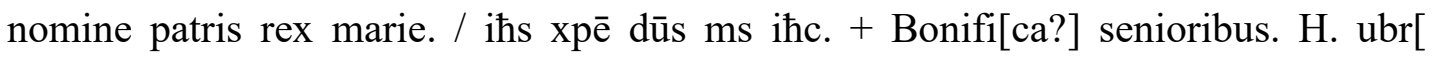
ini?]lur her / letus contra me. hee. larrhibus. excitatio pacis inter uirum / \& mulierum. $[\ldots \ldots \ldots . . .$. .A.B. \& alfa tibi reddit / uota fructu Leta lita tota tauta uel tellus uel ade uirescit.

(If you wish to go to your lord or to the king or to other men or to a council, then carry these letters with you. [Each of these will] then be [...] gracious [and 
pleasant]: “x x [ ] h .d.e.o.e.o.o.e.e.e.laf.d.R.U.fi.ð.f.p.A.x.Box.Nux. In the name of the Father, King. M. through. X. xix. xcs. xћ. iћ. + God. eo. God. deeo. Lafdruel. bepax. box. nux. bu. In the name of the Father, King, Mary. Jesus Christ my God, Jesus Christ. + Make virtuous elders. H. ubr[ ]lur her delight [read laetus] against me. hee. larrhibus. Build peace among men and women. [........] Alpha. Beta. And Alpha to you shall vows [be made] with delight. The court leet give favorable omens [from litare], all tauta or even the earth or even all that grows green").

Many of the letters in this obscure passage have been erased which makes interpretation of this text even more difficult. The fragmentary instructions state that the carrying of these letters will aid in an audience with one's superior or at a council. The erasures are made in specific places in the text, suggesting that a later reader did not perceive it as meaningless or nonsensical at all but as a powerful, even dangerous, ritual that could influence important political authorities. It is not clear when the erasures were made but they could have been made when the manuscript was separated from Egerton 3314 (fols. 9-72) after the dissolution of the monastery at Christ Church in $1539 .^{50}$

Some parts of the ritual's obscure passage can be interpreted, and it is clear that it draws upon at least three languages and alphabets (Latin, Greek, and Old English). Like the prayers in the Heavenly Letter, the passages in this text are either heavily corrupted or deliberately obscured. Certain vowels are grouped together, perhaps in a way to indicate a chant performance, but some consonants are combined in such a way that they cannot be vocalised, as seen in the first sequence: "d.e.o.e.o.o.e.e.e.laf.d.R.U.fi.ð.f.p.A.x.Box.Nux". Furthermore, letters from the English alphabet, such as eth ('ð’), appear among Latin words like deo and pax, perhaps indicating that different languages are involved in the same phrase. It is possible that these passages are anagrammatic, and that the reader must rearrange the 
letters in order to decipher the prayer. The presence of cross-markers beside these sequences also indicates that the letters form prayers that can be uttered with ritual gestures once they have been rearranged. It may also be the case that the letters have numerical significance, or that they are acronyms for words in prayers or phrases, similar to the abbreviation "M.M.L.I" for the names of the four evangelists in the preceding Heavenly Letter. For example, the first letters "d.e.o" may stand for the incipit to Psalm 101 ("Domine exaudi orationem meam", "O Lord hear my prayer"). ${ }^{51}$ However, this does not work for all of the letter combinations; there are no incipits to psalms, graduals, tracts, blessings, or collects beginning with three words that can be abbreviated to 'e.o.o', for instance, and I do not know of any that have laf in them. As letter rearrangement and cryptographic writing were well known in Anglo-Saxon England, it seems likely that this ritual's obscure phrases may draw upon different methods of encryption. ${ }^{52}$

A Latin prayer then follows this first sequence of letters, and it invokes God, Christ, and Mary, all through abbreviations. The prayer also refers to a king ("rex"), possibly relating to the king that is mentioned in the instructions. A second sequence of letters is then provided that develops the letter combinations of the first passage: “Deo.eo.deo.deeo.Lafdruel.bepax.box.nux.bu". The close similarities between the first and second sequences indicate that particular letters from a prayer are to be rearranged to form other powerful words or names. Lafdruel, for instance, may be the name of an angel or, if the ' $\mathrm{L}$ ' is actually an 'I' (it is difficult to tell with fading), it may be a variation of Iafeð, who is identified as one of Noah's sons in the notes on the six ages of the world on the previous folio $(139 v) .{ }^{53}$ Following this second obscure sequence of letters, the first Latin prayer is repeated with a reference to Mary after the mention of a king ("rex marie").

After these prayers have been repeated, another cross-marker begins a different passage that contains the most erasures. The first word of this section is difficult to read but 
"Bonifi[ca]" (imperative singular form of bonificare, 'to make virtuous') seems more plausible than the "Contra" offered by Thomas Cockayne. ${ }^{54}$ The word "senioribus" ('elders') can just be made out, and this could refer to members of a council that may be attended by the performer ("Gif bu wille ga... to gemote"). The capital letter ' $\mathrm{H}$ ' may be an abbreviation of a rank, position, or personal name - in a similar way to the conventional ' $\mathrm{N}$ ' abbreviation for Nomen - and the phrase "contra me" ('against me') may refer to individuals who are in opposition to the performer. ${ }^{55}$ The ritual may therefore have been written to counteract certain adversaries or accusations made against an individual.

Following this and the next words "hee larrhibus" - which I have not been able to identify - is a prayer that asks for peace among men and women. A large part of the text is then missing through erasure, and the next legible words read "A.B. \& alfa tibi reddit uota fructu". The phonetic spelling of alpha ("alfa") may work in conjunction with the first two Greek letters to spell out the Hebrew word for 'father' in 'a-b-a' (or Abba, cf. Mark 14. 36), but this is conjecture. The words that follow these Greek letters closely resemble Psalm 64 (verses 2-5), which describes vows made to God, God's forgiveness of sins, and the man who has won God's favor and earned a place in His courts:

Te decet hymnus deus in syon et tibi reddetur votum in ierusalem. Exaudi orationem meam ad te omnis caro veniet. Verba iniquiorum prevaluerunt super nos et impietatibus nostris tu propitiaberis. Beatus quem elegisti et adsumpsisti inhabitabit in tabernaculis tuis (emphasis mine). ${ }^{56}$

(Praise is due to you in Sion, O God, and to you vows shall be made in Jerusalem. Hear my prayer, to you will come all flesh. The words of the wicked have prevailed 
over us, and you will forgive us our sins. Blessed is he whom you choose and bring close, he will dwell in your courts).

If the words "alfa tibi reddit uota fructu" indicate a reference to Psalm 64, some logical connections can be made between the psalm and this text. It is a ritual to obtain favors from one's lord, king, or council, and this psalm describes the loyalty of God's subjects in their swearing of vows and their reward in gaining God's favor. God's chosen people are also permitted to dwell in the heavenly courts, and this would be highly applicable to a member of the king's council. The final few words of the text ("Leta lita tota tauta uel tellus uel ade uirescit") are again obscure but they suggest that the ritual concludes with a command for the court ("leta", cf. OE 'læð') to give favor to the performer and allow growth and fruition after a successful audience with one's superior. ${ }^{57}$

These are only tentative suggestions about how to interpret this highly obscure passage. As no other version of this ritual survives, its origin also remains unknown. However, the thematic connections that exist between this ritual and other materials in the collection may indicate that this text was composed around the time of the writing of the manuscript. The annals of Christ Church show an engagement with contemporary politics, and the Pachomius legend and obscure rituals reflect an interest in mystical language. The scribe or compiler may have attempted to reconstruct this heavenly language to influence particular circumstances in Canterbury in the 1070s. Despite the illegibility of much of this ritual, its opening instruction makes it clear that its user could obtain the favor of their superiors. If it were to be used by a lay person, then their lord would be a nobleman or even the king himself ("kyninge"). ${ }^{58}$ If it were to be used by a monk or cleric, their hlaforde would be the abbot or bishop, and the council or gemote would possibly be a chapter meeting. The King of heaven is invoked in a ritual that is to influence earthly lords and kings, and the 
reference to Mary may also parallel the earthly queen and her potential influence over the king. Given that the manuscript may have been written for a high-ranking ecclesiastic at Christ Church cathedral, this ritual may refer to an archbishop's lord - the pope or king - and the king's council or papal audience that he may have attended. The inclusion of this text in a manuscript made at Christ Church that also contains annals of contemporary events in Canterbury indicates that at this time the text was understood as a powerful ritual that could influence the highest authorities, and that its obscure letters were perceived as anything but "gibberish".

The ritual texts of Caligula A. Xv use highly obscure language juxtaposed with Christian invocations, cross-markers, and Scriptural references. It is likely that they contain deliberately obscure words and references taken from glossaries, glossed psalters, and hermeneutic texts, and that they were further obfuscated by strategies of textual concealment including encryption, unconventional abbreviation, and anagrammatic writing. Furthermore, the Heavenly Letter makes a connection between its obscure passages and the divine language of angels, and the ritual for favors claims that these letters have power over the highest authorities. Traditional scholarship argues that these and other "gibberish" texts provide examples of scribes replacing heathen formulas with nonsensical, misunderstood passages from Christian writings. However, from the evidence of Caligula A. xv and other contemporary manuscripts with encrypted writings, it seems more probable that these rituals demanded a highly skilled reader - like an abbot or bishop - to decipher their meaning. This alternative reading is further supported when one considers the other texts and images surrounding these rituals, and the likelihood that their obscure language arose out of ostentatious hermeneutic styles that were fostered in the same minster. The contents of Caligula A. xv indicate that the obscure language of these rituals developed from learned, 
Christian understandings of divine language, and that it was used to harness spiritual power to influence important events in post-Conquest Canterbury.

\section{THE “GIBBERISH” TEXTS IN CONTEXT}

The manuscript context of Caligula $\mathrm{A}$. $\mathrm{xv}$ provides information about the intellectual and political environments in which these obscure texts were written. The materials that surround the rituals reflect an interest in the cosmological power of language and a concern with contemporary politics in Canterbury in the 1070s. The illustration of the Pachomius legend recounts how divine mysteries were transmitted from heaven to religious authorities in mystical language, and this resonates strongly with the mysterious language of the ritual texts. The annals of Christ Church cathedral expose some political concerns of ecclesiastics in the aftermath of the Norman Conquest, and they provide possible incentives for the composition of at least one of these rituals. The wider manuscript context of Caligula A. Xv allows us to re-evaluate traditional views of "gibberish charms" and discover how at least one Christian scribe understood and valued these obscure rituals as mystical, Christian texts that could be used in their own challenging times.

\section{The Pachomius Legend and Patristic Sources}

At the top of folios 122v-123r is an illustration of the legend of St Pachomius (d. 348) above a None Aprilis table for the calculation of Easter, and it is clear that the illustration was planned at the same time as the first stage of writing. On folio $122 \mathrm{v}$, four figures are depicted in habits, one of which receives a scroll from an angel and has "Pachomius abbas" written above him. On this scroll is written the first words of the None Aprilis poem that outlines the calculation of Easter according to a nineteen-year cycle. On folio 123r, an angel is also shown receiving a scroll from Christ who is surrounded by two other angels, each carrying a 
banner. The images on both folios make it clear that the None Aprilis calculation of Easter was given to Pachomius by an angel who was sent by Christ.

The legend of Pachomius was well known in Anglo-Saxon England, and it seems to have often accompanied the None Aprilis poem. ${ }^{59}$ The original legend told of how Pachomius received his monastic rule from an angel, and St Jerome translated the Rule of Pachomius into Latin from Greek. In his preface to this work, Jerome described how the angel also gave Pachomius knowledge of a mystical alphabet that he used to communicate with his fellow bishops in secret:

angelus linguae mysticae scientiam dederit, ut scriberent sibi et loquerentur per alfabetum spiritale. ${ }^{60}$

(An angel gave knowledge of mystical speech so that they themselves might write and speak through a spiritual alphabet).

This mystical alphabet came directly from heaven and allowed Pachomius to converse with other ecclesiastics about spiritual matters. Another account of Pachomius' secret language is found in Gennadius's continuation of Jerome's other work De uiris illustribus:

In quibus alphabetum mysticis tectum sacramentis, velut humanae consuetudinis excendentem intelligentiam, clausit solis credo eorum gratiae vel meritis manifestum. ${ }^{61}$ 
[He wrote letters also to the associated bishops of his district, in an alphabet concealed by mystic sacraments so as to surpass customary human knowledge and only manifest to those of special grace]. ${ }^{62}$

Jerome introduced the Pachomius story into the Latin speaking world, and with it a legend about a divine alphabet that was given to Pachomius directly from heaven for secret communication.

In Anglo-Saxon England, this legend was adapted so that Pachomius was said to have received the correct calculation of Easter instead of a monastic rule. Byrhtferth of Ramsey described this version of the legend in his Enchiridion (written between 1010 and 1012), and he elaborated on the mysterious nature of the letters that Pachomius received from the angel:

$\mathrm{Nu}$ we habbað pæne Easterlice circul rihtlice amearcod and pa gerena pe him to gebyriað be dæle onem him awriten, nu gerist hyt to swutelianne mid ealre heortan meagolnysse hwanon he com and hwa hine gesette... 'Him sona of heofena mihte com unasecgendlic myrhð, engla sum mid blisse, se pas word geypte and pæne abbod gegladode and pas uers him mid gyldenum stafum awritene on pam handum betæhte, pe pus wæron on his spræce gedihte: None Aprilis norunt quinos eall to pam ende'. Nu we hig willað mid trahtnunge her geglengan and rihtlice heora gerena kyrtenum preostum gecyðan.

[Now that we have correctly written out the Easter cycle and alongside it written some of the mysteries that belong to it, it is fitting to expound with wholehearted earnestness where it came from and who established it... "Immediately there came to him [Pachomius] from the might of the heavens inexpressible joy, and a certain 
angel, with bliss, who disclosed these words and gladdened the abbot and delivered into his hands these verses, written with golden letters, which were composed thus in his language: The nones of April know five regulars all the way to the end"]. ${ }^{63}$

Unlike Jerome's account, where the angelic alphabet was secret and known only to Pachomius and his friends, Byrhtferth stated that the angel's golden letters (gyldenum stafum) were in Pachomius' own language (i.e. Egyptian). According to Byrhtferth, the letters of any language and alphabet have power to convey and calculate spiritual mysteries, providing that the recipient is able to discern their meaning. ${ }^{64}$ Byrhtferth's version is interesting for this added emphasis on the importance of vernacular languages in transmitting knowledge of divine phenomena. Helen Gittos has recently highlighted how late Anglo-Saxon ecclesiastics like Byrhtferth and Ælfric elevated English to the same status as Hebrew, Greek, and Latin in their exegetical works and own vernacular writings. ${ }^{65}$ Byrhtferth used the Pachomius story to promote English as a language capable of continuing Patristic traditions and explicating computistical enquiries and spiritual mysteries.

The Pachomius legend has important implications for Caligula A. Xv and its obscure texts. The scribe or compiler may have known Jerome's account of the legend, as other texts in the collection - such as the rituals (fols. 129r and 140r) and the dialogue between Jerome and Damasus (140v-141r) - reflect a keen interest in Jerome and other Patristic authorities. Jerome's De uiris illustribus (with Gennadius' additions) was also available in some AngloSaxon libraries, including the neighbouring abbey at St Augustine's, Canterbury. ${ }^{66}$ The Heavenly Letter provides the most direct connection with the Pachomius legend in its claim that it was brought to Rome by an angel from heaven. The ritual to obtain favors also resonates with the Pachomius legend as it uses secret, mystical language to influence important authorities. The ritual almost certainly demands the discernment of the reader or 
the person carrying the letters, and its encrypted language was probably known only to a small number of high-ranking ecclesiastics, much like Pachomius and his fellow bishops. ${ }^{67}$ In addition, Byrhtferth emphasized how vernacular languages are capable of transmitting divine mysteries, and the illustration of this legend is found in a collection of learned texts written in English and Latin. English letters appear alongside Greek and Latin in the "gibberish" sequences, and the rituals are all introduced by vernacular instructions. The illustration of the Pachomius legend is therefore an important component of this coherent collection, and it provides a convincing source of inspiration for the writing of these obscure rituals.

The combination and interweaving of different languages in Caligula A. xv has close correspondences with alphabet writing in earlier Continental manuscripts. Alessandro Zironi identifies sixteen Carolingian manuscripts dating from the eighth to tenth centuries that contain Greek, Latin, Hebrew, Chaldaic, Gothic, and runic alphabets, as well as the alphabet ascribed to Aethicus Ister. ${ }^{68}$ Zironi concludes that their scribes were inspired by the works of Patristic auctoritates such as Jerome, Donatus, Isidore, and Bede to investigate the origins and natures of ancient alphabets and to situate Germanic languages within a biblical paradigm. ${ }^{69}$ Carolingian interest in the ancient origins of languages and mystical writing is perhaps most explicit in Hrabanus Maurus' De inventione linguarum, which contains literal combinations of ancient and contemporary alphabets and graphemes. ${ }^{70}$ Hrabanus also included the runic alphabet among the scripts said to have come from Moses, and he used this alphabet to form symbols and diagrams of biblical names. ${ }^{71}$ Other studies have outlined how several other Irish and Continental writers used exotic languages to construct acrostics and cryptograms in Latin traditions, including Ermenrich of Ellwangen, Walafrid Strabo, Hincmar of Laon, Martin of Laon, Abbo of St Germain-des-Prés, Dubthach, Suadbar, and Duchess Hadwig, among others. ${ }^{72}$ 
There was an extensive interest in the origins and power of languages and alphabets across Europe in the ninth and tenth centuries, and by the tenth and eleventh centuries, Anglo-Saxon ecclesiastics were also interested in exotic languages, writing systems, cryptography, and obscure writing. ${ }^{73}$ It is therefore better to situate Caligula A. Xv and its "gibberish" texts within this wider intellectual culture. The combination of different graphemes in this manuscript's rituals reflects these antiquarian interests of Irish, Carolingian, and Anglo-Saxon scribes, who aligned contemporary alphabets with ancient ones, provided numerical equivalents for each letter, and composed prayers, images, and messages with them. ${ }^{74}$ The manuscript context surrounding these rituals also reveals an evident interest in Patristic auctoritates of Jerome, Pachomius, the Church Fathers, and Isidore, Bede, and Hrabanus (in Egerton 3314), indicating that their obscure language was perceived to have a mystical, Christian origin. The manuscript's use of multiple alphabets, strategies of textual concealment, and Patristic legends places Caligula A. Xv within this wider intellectual context of investigations into the origins of language and mystical alphabets. It seems highly likely that these texts arose from contemporary interests in obscurity, divine language, the ars grammatica, and Patristic traditions. ${ }^{75}$

In addition to the Pachomius legend, the obscure rituals of Caligula A. xv all invoke Church Fathers, including Saints Blaise (d. 316), Basil (d. 379), Damasus (d. 384), and Nicasius (d. 407 / 451), suggesting that the composer of these texts wished to give them the same credibility as Patristic legends. Except for Nicasius, all of these saints were contemporaries of Jerome and Pachomius, and Basil was heavily influenced by Pachomius' writings when he drew up his own monastic rule. When one considers the manuscript's focus on Patristic saints and obscure language, it seems likely that the scribe perceived these texts as secret, mystical prayers that could overcome physical and spiritual sickness, have the same salvific effect as the Eucharist, and influence important temporal authorities. 
The Political Environment of Canterbury in the 1070s

The second feature of the collection that can inform the "gibberish" rituals concerns contemporary politics in the aftermath of the Norman Conquest. The annals of Christ Church cathedral that were written by the original Anglo-Saxon scribe are found with an Easter table on folios $132 \mathrm{v}-135 \mathrm{r}$, beginning with the year 988 which records the death of Dunstan. ${ }^{76}$ The original scribe wrote entries up to the year 1076, which record the activities of both ecclesiastical and secular authorities. ${ }^{77}$ Certain other events in Canterbury are also recorded, including the sacking of the city by Danes in 1011, the translation of St Ælfheah’s relics to Christ Church in 1023, the burning of the cathedral in 1067, and Lanfranc's rebuilding of Christ Church in $1073 .^{78}$

Following the annal that records the death of Edward the Confessor in 1066, the scribe falls silent about the successions of secular rulers. Neil Ker thought that "the Conquest was not noticed by the original annalist" whereas Michael Swanton claimed that "the Norman Conquest was at first ignored" by the scribe. ${ }^{79}$ This scribe recorded only that King Edward died in 1066, and his silence about the Conquest is further highlighted by a later addition to this entry, which reads " 7 her com Willelm" ${ }^{80}$ This addition was made by the same Norman scribe who continued the annals in English from 1085 to Anselm's death in 1109 (135r136v). Different hands continue the annals in Latin from 1110 to 1268 (136v-139r), demonstrating that regular additions were made to this collection long after the Conquest.

Following the entry for the year 1066, the Anglo-Saxon scribe did not make mention of any other king and focused exclusively on Lanfranc's activities at Christ Church. These final entries read:

.mlxvi. Her forð ferde eadward kyng. (7 her com willelm) 
.mlxvii. Her on pison geare barn xpes [Cristes] cyrcan.

.mlxx. On pison geare com landfranc abbod 7 hine man halgode to bisceope to xpes [Cristes] cyrcan.

.mlxxiii. Her landfranc arcebiscop stuðolede xpes [Cristes] cyrcan .v. idus aprilis.

[Change of ink, same hand] .mlxxvi. On pison geare man sloh wælpeof . pridie kalendas Iunii.

(1066: Here King Edward died. [And here came William]. 1067: Here in this year Christ Church was burnt. 1070: In this year Abbot Lanfranc came and he was hallowed as bishop of Christ Church. 1073: Here Archbishop Lanfranc built Christ Church on 9 April. [Change of ink, same hand] 1076: In this year Wælpeof was killed on 31 May).

The scribal hand is the same throughout but the change in ink for the year 1076 indicates that the scribe wrote this collection around 1073 before returning to add in the entry concerning Wælpeof. These final entries show the scribe's evident concern with the legitimate successions of kings as well as religious leaders prior to the Conquest, and the exclusion of William from the annals is significant. Given that the scribe was working up until the year 1076, this suggests that he was reluctant to acknowledge William's invasion and coronation a decade after these events occurred.

The scribe's final entry is peculiar as it records the killing of a secular leader in opposition to William, Earl Wælpeof. According to the Peterborough Chronicle (Oxford, Bodleian Library, MS Laud Misc. 636, fols. 60v-61r), Wælpeof was involved in a plot to overthrow William that ended in disaster: 
Millesimo. lxxv. On pisum geare Willelm cyng geaf Raulfe eorle Willelmes dohtor Osbearnes sunu. 7 se ylca Raulf wæs bryttisc on his moder healfe, 7 his fæder wæs englisc, Raulf hatte, 7 wæs geboren on Norðfolce. Pa geaf se cyng his sunu pone eorldom on Norðfolc 7 Suðfolc, pa lædde he pet wif to Norðwic: pær wes pet brydeala mannum to beala. Đær wæs Roger eorl 7 Walpeof eorl 7 biscopas 7 abbotes, 7 ræddon pær swa pet hi woldon pone cyng gesettan ut of Englelandes cynedom; 7 hit wearð sona gecydd pam cynge to Normandige hu hit wæs geræd... 7 se cyng syððan com to Englalande 7 genam Roger eorl his mæg 7 gefestnode hine, 7 Walpeof eorl he genam eac... Walpeof eorl wes beheafdod on Winceastre, 7 his lic wearð gelead to Crulande. ${ }^{81}$

[1076 (read 1075): In this year King William gave the daughter of William fitz Osbern in marriage to Earl Ralph; and the same Ralph was Breton on his mother's side, and his father was English - called Ralph, and was born in Norfolk. Then the king gave his (Ralph's) son the earldom in Norfolk and Suffolk. He then led that woman to Norwich. That bride-ale there was death to men. Earl Roger was there, and Earl Waltheof, and bishops and abbots, and there planned that they would put the king out of the kingship of England. And it soon became known to the king in Normandy, how it was planned... And the king afterwards came to England and seized his (Ralph's) relative, Earl Roger, and secured him. And he took Earl Waltheof also... (In 1076) Earl Waltheof was beheaded in Winchester, and his body was led to Crowland]. ${ }^{82}$ 
The mention of Wælpeof's death in the annals of Caligula A. $\mathrm{xv}$ is interesting in that it is the only time that the scribe names a secular leader after $1066 .{ }^{83}$ These annals were written during this time of political uncertainty, unrest, and rebellion.

As Caligula A. xv was written at Christ Church in the 1070s, and probably for a highranking ecclesiastic with competency in several languages and an interest in the appointments and activities of Archbishops of Canterbury, it is possible that the collection was written for Lanfranc, who became Abbot of Christchurch and Archbishop of Canterbury in $1070{ }^{84}$ This possibility has interesting implications about the English scribe's treatment of the king and his opponents as he worked under a new Norman archbishop. Lanfranc was a close ally of William, and the absence of William in the annals is surprising, especially as a later Norman scribe felt the need to complete the earlier entry for 1066. The Anglo-Saxon scribe seems to have hesitated over writing William into English history during a time of rebellion, even though he would have been under instruction from a Norman superior. The entry for 1076 may also reflect the scribe's desire to remain neutral in his representation of a condemned rebel leader. Unlike other accounts of Wælpeof's death that present him in different ways as a traitor and as a martyr, this Anglo-Saxon scribe did not recognise Wælpeof either as an earl or as a rebel. ${ }^{85}$ Later sources also provide conflicting accounts of Lanfranc's opinion of Wælpeof, as some record that the archbishop exposed him as a traitor, whereas others recount Lanfranc's testimony to the earl's innocence. ${ }^{86}$ It is likely that the scribe returned to the original collection to add in this entry for 1076 because of Lanfranc's involvement in Wælbeof's trial. However, the English scribe also seems to have been careful not to reveal his political sympathies because the future of England and Canterbury still remained in the balance at the time of writing. These small details and silences in the annals indicate a politically-sensitive environment in which the obscure texts of Caligula A. xv were written, 
and they offer an historical context for the possible need for such rituals by an ecclesiastic who was deeply involved in the politics of this time.

Lanfranc's own political struggles within the Church also offer an explanation for the inclusion of powerful, mystical rituals. The scribe of Caligula A. Xv is known to have written the first series of Canterbury privileges, or "Lanfranc forgeries", in London, British Library, MS Cotton Claudius A. iii (fols. 7rv) ${ }^{87}$ These privileges concern the primacy of the Archbishop of Canterbury, and this same scribe wrote this document around the time when Lanfranc asserted his primacy over the Archbishop of York. ${ }^{88}$ An account of Lanfranc's dispute with this archbishop is also recorded in the Parker Chronicle (Cambridge, Corpus Christi College, MS 173), which was originally written in Winchester before it travelled to Canterbury before the late eleventh century. ${ }^{89}$ The final vernacular entry in this Chronicle for the year 1070 (fols. 31-32) was written by another scribe from Christ Church, almost certainly a member of the same confraternity as the Caligula A. xv scribe. ${ }^{90}$ The account of Lanfranc's dispute reads:

<AN> im.lxx. Her Landfranc se pe wæs abbod an Kadum com to Ængla lande, se efter feawum dagum wearð arcebiscop on Kantwareberig. He wæs gehaded .iiii. kalendas Septembris on his agenum biscopsetle fram eahte biscopum his underðioddum; ða opre ðe pær næron purh ærendrakan 7 purh gewrite atiwdon hwi hi ðær beon ne mihton. On pam geare THOMAS se wæs gecoran biscop to Eferwic com to Cantwareberig pæt man hine ðær gehadede efter pan ealdan gewunan. Đa ða Landfranc crafede fæstnunge his gehersumnesse mid aðswerunge, pa forsoc he 7 sæde pæt hit nahte to donne... Pa sona æfter pysan belamp pæt se arcebiscop LANDFRANC ferde to Rome 7 Thomas forð mid... Pa agann se arcebiscop Landfranc atywian mid openum gesceade pæt he mid rihte crafede pas pa he crafede 
7 mid strangan cwydan pæt ylce gefæstnode toforan pam papan Alexandre 7 toforan eallan pam concilium pe par gegadered was 7 swa ham foran. Æfter pysan com Thomas to Cantwarebyri 7 eal pæt se arcebiscop at him crafede eadmedlice 7 syppan pa bletsungan underfeng. ${ }^{91}$

[Here Lanfranc, who was abbot in Caen, came to England, who after a few days became archbishop in Canterbury. He was ordained on 29 August in his own bishop's seat by eight of his suffragan bishops; the others who were not there explained by messengers and by letter why they could not be there. In that year Thomas, who was chosen as bishop for York, came to Canterbury in order that he be ordained according to ancient custom. Then when Lanfranc demanded confirmation of his obedience with oath-swearing, he refused and said that he did not have to do it... Then soon after this it happened that the archbishop Lanfranc travelled to Rome, and Thomas along with him... Lanfranc began to explain with open reasoning that what he had demanded he had demanded by right, and confirmed the same strong argument before the pope Alexander and before all the council which was gathered there; and so (they) went home. After this Thomas came to Canterbury, and humbly fulfilled all that the archbishop demanded of him]. ${ }^{92}$

This particular episode describes a dispute between the most powerful archbishops in England that had to be taken to Rome before the Pope and his council. The entry was written down in Christ Church cathedral very soon after Lanfranc asserted his primacy at the beginning of his archiepiscopacy.

The obscure rituals in Caligula A. xv were written shortly after this event to assist a politically-influential figure, and it seems likely that an ecclesiastic like Lanfranc would have 
had cause to use such potent spiritual weapons during the upheavals of the 1070s. Indeed, these texts are presented as having a heavenly origin, and one claims to have power to win the favor of lords, kings, and councils. The materials that surround the ritual texts in Caligula A. XV suggest that their obscure language was perceived as anything but "gibberish" by the Anglo-Saxon scribe and compiler. The evidence suggests that Lanfranc would have likely known of this collection as he would have been the abbot and archbishop at Christ Church at the time of writing, and it is perhaps the case that the apparent "gibberish" of these rituals would have been understood - if not composed - by one of the highest-ranking authorities in England. Whatever the meaning of these enigmatic texts, they were very probably written by a highly educated ecclesiastic who had access to a wide range of materials in different languages at Canterbury cathedral. ${ }^{93}$ It is worth remembering that additional texts were added to the original manuscript (Caligula A. $\mathrm{xv}+$ Egerton 3314) after 1185 by a monk called Salomon who later became sub-prior of Christ Church cathedral, indicating that ecclesiastics of notable rank continued to use this collection and make additions to it. The likelihood of a well-educated scribe writing mystical texts with biblical and Patristic sources indicates that these rituals are heavily encrypted so that only those who knew how to read their mystical language could perform them correctly and unlock their divine power.

\section{CONCLUSIONS}

Traditional scholarship maintains that a significant proportion of Anglo-Saxon ritual texts contain "gibberish" that came about through the erroneous copying of source materials by Christian scribes. Some commentators argue that poorly educated monks attempted to replace heathen formulas in non-Christian rituals with words and phrases from Christian texts that they did not understand. Cotton Caligula A. xv (+ Egerton 3314) is an important witness to 
the Christian origins of some so-called "gibberish charms" that were written by a highly educated monk from Christ Church, Canterbury, possibly for the archbishop himself.

The original collection that was written by the Anglo-Saxon scribe reflects the learned nature of this manuscript. The rituals are found in a coherent collection that focuses on astronomy, the liturgical calendar, the temporal world, and salvation history. Although the wording of its texts is very obscure, it is clear that the rituals invoke God, Christ, the evangelists, and Patristic saints; they all use references from the psalms; some appear to contain words from an earlier hermeneutic composition and a Latin-Greek glossary from Canterbury; others reveal an interest in the sacred languages of Scripture; one claims to have been transmitted from heaven itself and it is even presented as equivalent to the Eucharist in its power.

The manuscript context of Caligula A. xv (+ Egerton 3314) indicates that in at least one case Patristic sources and hermeneutic techniques were used to reconstruct divine language that could be harnessed by a politically-active ecclesiastic residing in Canterbury in the aftermath of the Norman Conquest. The collection could have been written for Lanfranc, who would have probably valued rituals that used divine language to overcome all unknown evils and to influence his political opponents and superiors. It is tempting to conclude that Lanfranc knew about this collection in Caligula A. xv, and that if he himself had not composed the "gibberish" rituals, he may have known how to decrypt, read, and use them in testing circumstances at the beginning of his archiepiscopacy according to hermeneutic styles known in England and the Continent.

Many other manuscripts that are believed to contain "gibberish" materials were also written in high-status minsters by educated scribes, where Patristic writings would have been available, and where hermeneutic styles were embraced and eagerly promoted. These texts have strong correspondences with other Carolingian and Anglo-Saxon manuscripts 
containing cryptograms, alphabet series, glossaries of obscure words, and numerical and epigraphical systems for language manipulation. ${ }^{94}$ Rather than providing evidence of scribal corruption and attempts to replace heathen formulas, these "gibberish" texts should be read within the wider intellectual context of medieval language and alphabet studies. They perhaps reflect the efforts of English theologians to conceal spiritual mysteries in obscure language like that spoken by angels, and entertaining this alternative approach to will undoubtedly uncover more exciting clues about encoded secrets in "gibberish" texts. 


\section{NOTES}

I would like to express my thanks and gratitude to Dr Helen Gittos (Oxford University), Dr Michael D. J. Bintley (Canterbury Christ Church University), Dr Sinead O’Sullivan (Queen's University Belfast), Dr Pádraic Moran (NUI Galway), Dr Tom Birkett (University College Cork), and Prof Susan Irvine (University College London) for offering their helpful advice in revisions of this article. I also thank the Leverhulme Trust for funding this research project.

${ }^{1}$ Felix Grendon, “The Anglo-Saxon Charms”, The Journal of American Folklore, 22 (1909), 114.

${ }^{2}$ Grendon, “Anglo-Saxon Charms", pp. 124, 127.

${ }^{3}$ Godfrid Storms, Anglo-Saxon Magic (The Hague: Nijhoff, 1948), p. 297.

${ }^{4}$ Storms, Anglo-Saxon Magic, pp. 1, 297.

${ }_{5}^{5}$ Paul Cavill, Anglo-Saxon Christianity (London: Harper Collins, 1999), p. 25. For similar arguments, see George Hardin Brown, "Solving the 'Solve' Riddle in B. L. MS Harley 585”, Viator, 18 (1987), 45-51; R. A. Banks, "The Uses of Liturgy in the Magic, Medicine, and Poetry of the Anglo-Saxons", in The Timeless and the Temporal: Writings in honour of John Chalker by Friends and Colleagues, ed. Elizabeth Maslen (Exeter: Short Runn Press, 1993), pp. 19-40; Lois Bragg, "Runes and Readers: In and Around 'The Husband's Message", Studia Neophilologica, 71 (1999), 34-50; Rosanne Hebing, “The Textual Tradition of Heavenly Letter Charms in Anglo-Saxon Manuscripts", in Secular Learning in Anglo-Saxon England: Exploring the Vernacular, ed. Lázló Sándor Chardonnens and Bryan Carella (Amsterdam: Rodopi, 2012), pp. 203-22; Lea Olsan, "The Marginality of Charms in Medieval England", in The Power of Words: Studies on Charms and Charming in Europe, ed. James Kapaló, Éva Pócs, and William Ryan (Budapest: Central European Univ. Press, 2013), pp. $136-7$.

${ }^{6}$ See especially Karen Louise Jolly, Popular Religion in Late Saxon England: Elf Charms in Context (Chapel Hill: Univ. of North Carolina Press, 1996), pp. 117-18; Leslie Arnovick, Written Reliquaries: the Resonance of Orality in Medieval English Texts (Amsterdam: John Benjamins, 2006), pp. 27-60.

${ }^{7}$ See P. J. Willetts, “A Reconstructed Astronomical Manuscript from Christ Church Library Canterbury”, The British Museum Quarterly, 30 (1965), 22-30.

${ }^{8}$ Neil R. Ker, Catalogue of Manuscripts Containing Anglo-Saxon, rev. edn (Oxford: Clarendon, 1990), pp. 1736; Helmut Gneuss, Handlist of Anglo-Saxon Manuscripts: a List of Manuscripts and Manuscript Fragments Written or Owned in England up to 1100 (Tempe, AZ: Arizona Centre for Medieval and Renaissance Studies, 2001), pp. 61, 74. See also Karen Louise Jolly, “Tapping the Power of the Cross: Who and for Whom?”, in The 
Place of the Cross in Anglo-Saxon England, ed. Catherine E. Karkov, Sarah Larratt Keefer, and Karen Louise Jolly (Woodbridge: Boydell, 2006), pp. 63-5; Roy Liuzza, Anglo-Saxon Prognostics: an Edition and Translation of Texts from London, British Library, MS Cotton Tiberius A. III (Cambridge: D. S. Brewer, 2010), pp. $9-12$

${ }^{9}$ Also noted by Gneuss, Handlist, p. 74; Donald G. Scragg, A Conspectus of Scribal Hands Writing English, 960-1100 (Cambridge: D. S. Brewer, 2012), p. 35; British Library Catalogue Online, <http://www.bl.uk/onlinegallery/onlineex/>, accessed 16 August 2017; Takako Kato, "London, British Library, Cotton Caligula A. xv", The Production and Use of English Manuscripts 1060 to 1220, ed. Orietta Da Rold, Takako Kato, Mary Swan, and Elaine Treharne (University of Leicester, 2010; last updated 2013), <http://www.le.ac.uk/english/em1060to1220, accessed 16 August 2017.

10 Reproduced and interpreted in Mindy MacLeod and Bernard Mees, Runic Amulets and Magic Objects (Woodbridge: Boydell, 2006), p. 120.

${ }^{11}$ A facsimile of this folio is printed in Lázló Sándor Chardonnens, Anglo-Saxon Prognostics, 900-1100: Study and Texts (Leiden: Brill, 2007), p. 198.

12 “1070: In this year Abbot Lanfranc came and he was anointed as bishop of Christ Church”. Transcriptions of texts from this manuscript are my own and I have silently expanded abbreviations. I have also indicated the separation of lines within texts as they appear on the manuscript page because if letter rearrangements are to be used then line spacing may be important.

${ }^{13}$ See Gneuss, Handlist, p. 74.

${ }^{14}$ Stephanie Hollis, "Scientific and Medical Writings", in A Companion to Anglo-Saxon Literature, ed. Phillip Pulsiano and Elaine Treharne (Oxford: Blackwell, 2001), pp. 191-2. See also Hebing, "Heavenly Letter Charms", pp. 218-21.

${ }^{15}$ Jolly, "Tapping the Power of the Cross", pp. 63-70.

16 Jolly, "Tapping the Power of the Cross", pp. 63-5.

${ }^{17}$ Chardonnens, Anglo-Saxon Prognostics, pp. 36-7; Liuzza, Anglo-Saxon Prognostics, pp. 59-76.

${ }^{18}$ Liuzza, Anglo-Saxon Prognostics, pp. 76-7.

19 The very nature of the Anglo-Saxon "charms" genre is more thoroughly critiqued in my forthcoming book “Charms”, Liturgies, and Secret Rites in Early Medieval England (London: Boydell, 2018).

${ }^{20}$ The Vitellius Psalter: Edited from British Museum MS Cotton Vitellius E. xviii, ed. James L. Rosier (Ithaca, N.Y.: Cornell Univ. Press, 1962), pp. xx-xxi; Phillip Pulsiano, “The Prefatory Matter of London, British 
Library, Cotton Vitellius E. xviii”, in Anglo-Saxon Manuscripts and their Heritage, ed. Phillip Pulsiano and Elaine Treharne (Aldershot: Ashgate, 1998), pp. 85-116; Martha D. Rust, "The Art of Beekeeping Meets the Arts of Grammar: A Gloss of 'Columcille’s Circle”, Philological Quarterly, 78 (1999), 376-8.

${ }^{21}$ See Alfwine's Prayerbook: London, British library, Cotton Titus D. xxvi + xxvii, ed. Beate Günzel, HBS, 108 (London: Boydell, 1993), p. 3, 78; The Liber Vitae of the New Minster and Hyde Abbey Winchester: British Library Stowe 944, ed. Simon Keynes, EEMF, 26 (Copenhagen: Rosenkilde \& Bagger, 1996), p. 67, note 13; Pulsiano, "Prefatory Matter", p. 102. On the correspondences between these manuscripts, see Ker, Catalogue, pp. 173-6, 264-6, 298-301; Chardonnens, Anglo-Saxon Prognostics, pp. 6, 53-62; Liuzza, Anglo-Saxon Prognostics, pp. 3-25; Catherine E. Karkov, "Abbot Ælfwine and the Sign of the Cross", in Cross and Cruciform in the Anglo-Saxon World: Studies to Honor the Memory of Timothy Reuter, ed. Sarah Larratt Keefer, Karen Louise Jolly, and Catherine E. Karkov (Morgantown: West Virginia Univ. Press, 2010), pp. 123-5.

${ }^{22}$ For a digitisation of St John's 17 and an excellent, extensive commentary, see Faith Wallis, The Calendar and the Cloister: Oxford, St John's College, MS 17 (Montreal, 2007): 〈http://digital.library.mcgill.ca/ms-17> accessed 18 October 2017. See also Chardonnens, Anglo-Saxon Prognostics, pp. 31, 221-2.

${ }^{23}$ This ritual for fever is also printed in Thomas Oswald Cockayne, Leechdoms, Wortcunning, and Starcraft of Early England: being a Collection of Documents, for the Most Part Never Before Printed, Illustrating the History of Science in this Country Before the Norman Conquest, 3 vols. (London: Longman, 1864-6), III, 295; Storms, Anglo-Saxon Magic, p. 300. Another similar ritual against fever is found in Cambridge, Queen's College, MS 7 (52r; s. xii, unknown origin). It uses similar "gibberish" and cross-markers to Wið Gedrif, and it has the title Medicina contra febres ("Medicine against fever"), indicating that these kinds of formulas were perceived to be medically effective by later scribes and readers. See Thomas Hartwell Horne, A Catalogue of the Library of the College of St. Margaret and St. Bernard, Commonly Called Queen's College in the University of Cambridge, 2 vols. (London: S. and R. Bentley, 1827), II, 999-1000; M. R. James, A Descriptive Catalogue of the Western Manuscripts in the Library of Queen's College, Cambridge (Cambridge: Cambridge Univ. Press, 1905), pp. 7-8; Storms, Anglo-Saxon Magic, p. 306.

24 "The serpents which in Italy are known by the name of 'boa', render these accounts far from incredible, for they grow to such a vast size, that a child was found entire in the stomach of one of them, which was killed on the Vaticanian Hill during the reign of the Emperor Claudius. These are nourished, in the first instance, with the milk of the cow, and from this they take their name... 'Boa' is the name given to a malady which appears in the form of red pimples upon the body; for its cure the patient is scourged with a branch of elder... The eruption 
called 'boa' is treated with cow-dung, a fact to which it is indebted for its name", Pliny the Elder, The Natural History of Pliny, trans. John Bostock, 6 Vols. (London: H. B. Bohn, 1856-93), II, 262; V, 24, 360.

${ }^{25}$ Vitellius Psalter, ed. Rosier, p. 276. Some Gallican psalters use the word olla instead of lebes, such as the Eadwine Psalter (Cambridge, Trinity College, MS R. 17. 1) that was written in Christ Church, Canterbury c. 1150, see Eadwine's Canterbury Psalter, ed. Fred Harsley, EETS o.s., 92, 2 vols. (London: N. Trübner, 1889), II, 191; Peter J. Lucas and Jonathan Wilcox, Anglo-Saxon Manuscripts in Microfiche Facsimile, Vol. 16: Manuscripts Relating to Dunstan, Alfric, and Wulfstan; the "Eadwine Psalter" Group, ed. Alger N. Doane (Tempe, Arizona: ACMRS, 2008), p. 43. The Vitellius Psalter, quoted above, has many strong textual connections with Caligula A. xv and it is therefore likely that a similar psalter was being used by the Caligula scribe in the copying, composition, or encryption of this text. It is, however, worth noting that the Eadwine Psalter is a triple psalter containing the Romanum, Gallicanum, and Hebraicum versions of the psalms, suggesting that earlier Hebraicum versions were available in Canterbury Cathedral at the time of this ritual's writing.

${ }^{26}$ Vitellius Psalter, ed. Rosier, pp. 276-7.

${ }^{27}$ Michael Lapidge, “The Hermeneutic Style in Tenth-Century Anglo-Latin Literature”, ASE, 4 (1975), 80-1.

${ }^{28}$ Jolly, "Tapping the Power of the Cross", p. 63.

${ }^{29}$ Cockayne, Leechdoms, III, 295.

${ }^{30}$ See J. F. Shrewsbury, “The Saints and Epidemic Disease”, Birmingham Medical Review, 19 (1956), 215;

Donald R. Hopkins, The Greatest Killer: Smallpox in History (Chicago: Univ. of Chicago Press, 2002), p. 101. A similar version of this ritual was also added to the Royal Prayerbook in the twelfth century (London, BL, Royal 2 A. xx, 52r), see Storms, Anglo-Saxon Magic, p. 316; Alger N. Doane, Anglo-Saxon Manuscripts in Microfiche Facsimile, Vol. 1: Books of Prayers and Healing (Binghamton, N.Y.: CEMERS, 1994), p. 58.

${ }^{31}$ Sumner J. Yaffe, Jacob V. Aranda et. al., Neonatal and Pediatric Pharmacology: Therapeutic Principles in Practice, $4^{\text {th }}$ rev. edn (Philadelphia, P.A.: Lippincott Williams and Wilkins, 2010), p. 875.

${ }^{32}$ See Storms, Anglo-Saxon Magic, pp. 275-9, 295-6, 306.

${ }^{33}$ Grendon, “Anglo-Saxon Charms”, pp. 114-15, 151, 202, 233 (texts AA 13, D 7); Storms, Anglo-Saxon Magic, pp. 297, 300-1.

${ }^{34}$ Cockayne was the only editor to print these texts together, Cockayne, Leechdoms, III, 288-90.

${ }^{35}$ See Hebing, "Heavenly Letter Charms". Another ritual in the early eleventh-century manuscript London, British Library, MS Harley 585 (s. $\mathrm{xi}^{1}$, possibly Winchester) also claims to have been brought from heaven by 
an angel, and it uses “a mixture of Hebrew, Aramaic, Latin and Greek", Storms, Anglo-Saxon Magic, p. 294.

However, this ritual from Harley 585 does not make the same claims of equivalence with the psalms and the Eucharist.

${ }^{36}$ Jolly, "Tapping the Power of the Cross", p. 64.

${ }^{37}$ See especially Frederick S. Paxton, “Anointing the Sick and the Dying in Christian Antiquity and the Early Medieval West", in Health, Disease and Healing in Medieval Culture, ed. Sheila Campbell, Bert Hall, and David Klausner (London: MacMillan, 1992), pp. 93-102; Jolly, Popular Religion, pp. 154-60; Victoria Thompson, Dying and Death in Later Anglo-Saxon England (Woodbridge: Boydell, 2004), pp. 60-88.

${ }^{38}$ Alternatively, while "sobrius" is a common enough Latin word, this passage bears resemblance to Book IX, Chapter 21 of Lucius Apuleius' Metamorphoses, which also places adjectives for "sober" and "religious" together: "vir alioqui gravis, et sobriae religionis observatione famosus"; see Ronald E. Latham, David R Howlett, and Richard K. Ashdowne, et. al Dictionary of Medieval Latin for British Sources, (Oxford, 19752013), <http://logeion.uchicago.edu/index.html\#sobrius>, accessed 16 August 2017. Printed in Lucius Apuleius, L. Apuleii Madaurensis: Opera Omnia, ed. Gustav F. Hildebrand (Leipzig: Sumptibus C. Cnoblochii, 1843), p. 154.

39 See Latham, Howlett, and Ashdowne, Dictionary of Medieval Latin for British Sources, <http://logeion.uchicago.edu/index.html>, accessed 16 August 2017.

${ }^{40}$ See A. G. Rigg and G. R. Wieland, "A Canterbury Classbook of the Mid-Eleventh Century (the 'Cambridge Songs’ Manuscript)", ASE, 4 (1975), 113-30.

${ }^{41}$ Lapidge, "Hermeneutic Style”, 77-85.

${ }^{42}$ See Lapidge, "Hermeneutic Style”, pp. 79-81. For an edition of Frithegod's work, see Frithegodi Monachi Breuiloquium Vitae Beati Wilfredi, ed. Alistair Campbell (Zürich: Thesaurus Mundi, 1950). On intellectual engagements with Hebrew in Anglo-Saxon England, see Damian Fleming, “Hebraeam scire linguam: Bede's Rhetoric of the Hebrew Truth", in Imagining the Jew: Jewishness in Anglo-Saxon Literature and Culture, ed. Samantha Zacher (Toronto: Univ. of Toronto Press, 2016), pp. 63-78; "Hebrew Words and English Identity in Educational Texts of Ælfric and Byrhtferth”, in Latinity and Identity in Anglo-Saxon England, ed. Rebecca Stephenson and Emily Thornbury (Toronto: Univ. of Toronto Press, 2016), pp. 138-57. On the study of Greek and Hebrew in Ireland, see Pádraic Moran, "Hebrew in Early Irish Glossaries", Cambrian Medieval Celtic Studies, 60 (2010), 1-21; “A Living Speech? The Pronunciation of Greek in Early Medieval Ireland”, Ériu, 61 (2011), 29-57. 
${ }^{43}$ For "basileus" see Corpus Glossariorum Latinorum, ed. George Goetz, 7 Vols (Leipzig: B. G. Teubneri, 1888-1923), IV, 24, 210. It also appears in Book 3 of Bella Parisiacae Urbis by Abbo of St-Germans-des-Près, see Lapidge, "Hermeneutic Style", p. 79; Latham, Howlett, and Ashdowne, Dictionary of Medieval Latin for British Sources, <http://logeion.uchicago.edu/index.html\#Basileus>, accessed 16 August 2017. For details of Cotton Claudius A. i, see British Library Catalogue Online, <http://www.bl.uk/manuscripts/Viewer.aspx?ref=cotton_ms_claudius_a_i_f005r>, accessed 16 August 2017.

${ }^{44}$ See John H. Hessels, An Eighth-Century Latin-Anglo-Saxon Glossary: Preserved in the Library of Corpus Christi College, Cambridge (MS. No. 144) (Cambridge: Cambridge Univ. Press, 1890), p. 93; A Late EighthCentury Latin-Anglo-Saxon Glossary: Preserved in the Library of the Leiden University (MS. Voss. Qo Lat. No. 69) (Cambridge: Cambridge Univ. Press, 1906), p. 26; Isidore of Seville, The Etymologies of Isidore of Seville, trans. Stephen A. Barney, W. J. Lewis, J. A. Beach, and Oliver Berghof (Cambridge: Cambridge Univ. Press, 2006), p. 345.

${ }^{45}$ See Michael Lapidge, “The School of Theodore and Hadrian”, ASE, 15 (1986), 54-67.

46 For Corpus 144, see Parker Library On the Web (Cambridge, 2009), <https://parker.stanford.edu/parker/actions/manuscript_description_long_display.do?ms_no=144>, accessed 16 August 2017.

${ }^{47}$ See Isidore of Seville, Etymologiarum sive originum, ed. W. M. Lindsay, 2 vols (Oxford: Clarendon, 1911), I, 1, 11-12; Ælfric, Alfrics Grammatik und Glossar, ed. Julius Zupitza (Berlin: Weidmannsche Buchhandlung, 1880), p. 2.

${ }^{48}$ Isidore, Sententiae, Patrologia Latina, 83 (1862), I, 18, col. 576C-577A.

${ }^{49}$ Vivien Law, Wisdom, Authority and Grammar in the Seventh Century: Decoding Vigilius Maro Grammaticus (Cambridge: Cambridge Univ. Press, 1995), p. 94.

${ }^{50}$ See Willetts, “A Reconstructed Astronomical Manuscript”, p. 28. John Dee’s “Jupiter” sign and handwriting appear in Egerton 3314, showing that this sixteenth-century astronomer and member of the Elizabethan court owned this manuscript before it was separated from Caligula A. xv, see Chardonnens, Anglo-Saxon Prognostics, pp. 36-7; Liuzza, Anglo-Saxon Prognostics, pp. 9, 11.

${ }^{51}$ Eadwine's Canterbury Psalter, ed. Harsley, II, 173.

${ }^{52}$ On knowledge of letter rearrangement and cryptographic writing in England, see Wilhelm Levison, England and the Continent in the Eighth Century: The Ford Lectures (Oxford: Clarendon, 1943), 291-4; Michael Lapidge, “Aldhelm's Latin Poetry and Old English Verse”, Comparative Literature, 31 (1979), 209-31; David 
A. E. Pelteret, "A Cross and an Acrostic: Boniface's Prefatory Poem to his Ars grammatica", in Cross and Cruciform in the Anglo-Saxon World: Studies to honor the memory of Timothy Reuter, ed. Sarah Larratt Keefer, Karen Louise Jolly, and Catherine E. Karkov (Morgantown, W.V.: West Virginia Univ. Press, 2010), pp. 53102; Edward Christie, "By Means of a Secret Alphabet: Dangerous Letters and the Semantics of Gebregdstafas (Solomon and Saturn I, Line 2b)”, Modern Philology 109 (2011), 145-70. See also notes 20 and 21.

53 “Noe hæfde .iii. suna pus wæron hatene / Sem . Cham . Iafeð . of pam preom awocan 7 forð / coman .Lxxii. peoda . frā(m) Iafeðe .xv. 7 frā(m) Chame / .xxx. 7 fram Seme .xxvii"; "Noah had three sons, who were thus called Sem, Cham, and Jafeth. Of these three awoke and came forth seventy-two nations: from Jafeth fifteen, and from Cham thirty, and from Sem twenty-seven".

54 See Cockayne, Leechdoms, III, 290. For bonificare see Latham, Howlett, and, Ashdowne, Dictionary of Medieval Latin for British Sources, <http://logeion.uchicago.edu/index.html>, accessed 16 August 2017.

${ }^{55}$ I would like to thank Marilina Cesario for her helpful insight on this possibility.

${ }^{56}$ Eadwine's Canterbury Psalter, ed. Harsley, II, 106-7.

${ }^{57}$ The Dictionary of Medieval Latin for British Sources defines Leta as a "court leet" or "a division of a county smaller than a hundred", Latham, Howlett, and, Ashdowne, Dictionary of Medieval Latin for British Sources, <http://logeion.uchicago.edu/index.html\#leta>, accessed 16 August 2017. Lita is the imperative singular form of litare, which is defined as "obtain / give favorable omens from sacrifice; make acceptable offering to" in Words by William Whitaker (Notre Dame, 1993-2007), <http://archives.nd.edu/cgi-bin/words.exe>, accessed 16 August 2017.

58 Jolly believes that this ritual would have been used as an amulet by a lay user, see Jolly, “Tapping the Power of the Cross", p. 64.

${ }^{59}$ For a discussion of Anglo-Saxon manuscripts containing the Pachomius legend, see Charles Jones, “A Legend of St. Pachomius", Speculum, 18 (1943), 198-210.

${ }^{60}$ Jerome, Pachomiana Latina: Règle et épîtres de S. Pachôme, épître de S. Théodore et 'Liber' de S. Orsiesius, ed. Amand Boon (Louvain: Universitebibliotheek, 1932), p. 9.

61 Jerome, Hieronymus liber de viris inlustribus: Gennadius liber de viris inlustribus, ed. Ernest Cushing Richardson (Leipzig: Hinrichs, 1896), pp. 63-4.

${ }^{62}$ Ernest Cushing Richardson, Theodoret, Jerome, Gennadius, and Rufinus: Historical Writings, A Select Library of Nicene and Post-Nicene Fathers of the Christian Church, 2d series, 3 (Edinburgh: Clark, 1979), p. 387. See also Christie, “Secret Alphabet”, p. 166. 
${ }^{63}$ Byrhtferth of Ramsey, Byrhtferth's Enchiridion, ed. and trans. Peter S. Baker and Michael Lapidge, EETS s.s., 15 (Oxford: Oxford Univ. Press, 1995), III, 2, pp. 138-9. For the dating of this work, see pp. xxvii-xxviii and Rebecca Stephenson, "Scapegoating the Secular Clergy: the Hermeneutic Style as a Form of Monastic SelfDefinition", ASE, 38 (2009), 103; Rebecca Stephenson, The Politics of Language: Byrhtferth, Alfric, and the Multilingual Identity of the Benedictine Reform (Toronto: Univ. of Toronto Press, 2015), p. 39.

${ }^{64}$ In his homily for mid Lent Sunday Ælfric also stated that while the appearance of letters is mysterious and appealing, their true value is to be found in the divine secrets that they convey: "oft gehwa gesihð fægere stafas awritene. ponne herað he pone writere 7 pa stafas 7 nat hwæt hi mænað; Se ðe cann pæra stafa gescead. he herað heora fægernysse. 7 ræt pa stafas. 7 understent hwæt hi gemænað... Nis nah genoh $b(æ t)$ ðu stafas scawie. buton pu hi eac ræde. 7 p(æt) andgit understande... pa bec wæron awritene be criste ac p(æt) gastlice andgit wæs ðam folce digle oð $\mathrm{p}(æ t)$ crist sylf com to mannum 7 geopenade pæra boca diglnysse: æfter gastlicum andgite”, Ælfric, Alfric's Catholic Homilies: the First Series, Text, ed. Peter Clemoes, EETS s.s., 17 (Oxford: Oxford Univ. Press, 1997), pp. 277-8; “Often someone sees lovely letters written then praises the writer and the letters, and not know what they mean. He who knows how to understand those letters praises their loveliness, and reads the letters, and understands what they mean... it is not enough that you behold letters without also reading them and understanding their sense... These books were written concerning Christ, but the spiritual sense was hidden from the people, until Christ himself came to men, and opened the books' secrets, according to the spiritual sense".

${ }^{65}$ Helen Gittos, "The Audience for Old English Texts: Ælfric, Rhetoric and "the Edification of the Simple", ASE, 43 (2014), 264.

${ }^{66}$ These manuscripts are Hereford, Hereford Cathedral Library, MS O.III.2 (s. ix ${ }^{2}$, France, prov. Salisbury); Oxford, Bodleian Library, MS Bodley 391 (s. xi ${ }^{\mathrm{ex}}$, St Augustine's, Canterbury); Salisbury, Cathedral Library, MS 88 (xi ${ }^{\text {ex }}$, Salisbury), see Gneuss, Handlist, pp. 55, 94, 109-10.

${ }^{67}$ The ritual to obtain favors also instructs the performer to write "pas stafas" so that they may be carried on the person, and in Byrhtferth's account of the Pachomius legend golden letters ("gyldenum stafum awritene") were delivered into Pachomius' hands (“on pam handum betæhte") which he later carried with him.

68 Alessandro Zironi, "Marginal Alphabets in the Carolingian Age: Philological and Codicological Considerations", in Rethinking and Recontextualizing Glosses: New Perspectives in the Study of Late AngloSaxon Glossography, ed. Patrizia Lendinara, Loredana Lazzari, and Claudia Di Sciacca (Porto: Fédération Internationale des Instituts d'Études Médiévales, 2011), pp. 353-71. See also René Derolez, “Ogam, 'Egyptian', 
'African' and 'Gothic' Alphabets: some Remarks in Connection with Codex Bernensis 207', Scriptorium, 5 (1951), 3-19; René Derolez, Runica Manuscripta: The English Tradition (Brugge: De Tempel, 1954), pp. 52-73, 90-4, 120-37, 174-92, 217-19; Bernhard Bischoff, Mittelalterliche Studien, Ausgewählte Aufsätze zur Schriftkunde und Literaturgeschichte, 3 Vols. (Stuttgart: Hiersemann, 1966-1981), II, 34-51; III, 73-111, 120 48; Walter Berschin, "Elements in Medieval Latin Manuscripts", in Sacred Nectar of the Greeks: the Study of Greek in the West in the Early Middle Ages, ed. M. W. Herren (London: King's College London Medieval Series, 1988), pp. 85-104.

${ }^{69}$ Zironi, "Marginal Alphabets", p. 369.

${ }^{70}$ Hrabanus Maurus, B. Rabani Mauri Fuldensis Abbatis et Moguntini Archiepiscopi: Omnia Opera, PL, 112 (1852), col. 1579-1584. It is also worth noting that the original manuscript contained some astronomical materials attributed to Hrabanus Maurus in Egerton 3314, indicating that the scribe or compiler was familiar with his works.

${ }^{71}$ An interesting parallel to Hrabanus' claim can be found in a miniature of the crucifixion from an eleventhcentury psalter from Hastières (Munich, Bayerische Staatsbibliothek, Clm 13067, fol. 17v), where the inscription on Christ's cross contains Latin, Greek, and runic letters. See Sabrina Longland, "Pilate Answered: What I have Written I Have Written”, The Metropolitan Museum of Art Bulletin, 26 (1968), 420-1; Tom Birkett, Reading the Runes in Old English and Old Norse Poetry (Abingdon: Routledge, 2017), pp. 14-15. I would like to thank Tom Birkett for bringing this to my attention.

${ }^{72}$ Walter Berschin, Greek Letters in the Latin Middle Ages: from Jerome to Nicholas of Cusa, trans. Jerold C. Frakes (Washington: Catholic Univ. of America Press, 1988), pp. 126-56; Jan M. Ziolkowski, "Theories of Obscurity in the Latin Middle Ages”, Mediaevalia, 19 (1996), 101-70. For further, see Genny L. Tunbridge, “A Study of Scribal Practices in Early Irish and Anglo-Saxon Manuscripts" (unpubl. D. Phil dissertation, Oxford Univ., 1992), pp. 2-7; Sinead O'Sullivan, “Obscurity, Pagan Lore, and Secrecy in Glosses on Books I-II from the Oldest Gloss Tradition", in Carolingian Scholarship and Martianus Capella: Ninth-Century Commentary Traditions on "De Nuptiis" in Context, ed. Mariken Teeuwen and Sinead O'Sullivan (Turnhout: Brepols, 2011), pp. 99-121.

${ }^{73}$ See, for example, Pulsiano, "Prefatory Matter", pp. 97-9; William Schipper, "Hrabanus Maurus in AngloSaxon England: In honorem sanctae crucis", in Early Medieval Studies in memory of Patrick Wormald, ed. Stephen D. Baxter, Catherine Karkov, Janet L. Nelson, and David Pelteret (Farnham: Ashgate, 2009), pp. 285-6; Marco Mostert, "Relations between Fleury and England", in England and the Continent in the Tenth Century: 
Studies in honour of Wilhelm Levison (1876-1947), ed. David Rollason, Conrad Leyser, and Hannah Williams (Turnhout: Brepols, 2010), pp. 191-3. See also notes 20, 21, and 52.

${ }^{74}$ On the use of Greek to deliberately obscure texts by Carolingian scribes, see Sinead O'Sullivan, "The Sacred and the Obscure: Greek and the Carolingian Reception of Martianus Capella”, Journal of Medieval Latin, 22 (2012), 67-94.

75 Isidore of Seville's approach to language, alphabets, and obscurity had possibly the greatest influence on medieval philosophies of language, see especially Isidore, Sententiae, col. 576C-577A; Isidore, Etymologiarum, I, I.3.1, IX, 1.1.3. These interests are also apparent in inscriptions on swords, religious objects, and amulets, see especially Don C. Skemer, Binding Words: Textual Amulets in the Middle Ages (Pennsylvania: Pennsylvania State Univ. Press, 2006), esp. pp. 75-124.

${ }^{76}$ One entry for the year 925 which records Dunstan's birth was added by the main scribe above the Easter table and in the margin of folio 133r. A facsimile of these first folios can be found in G. N. Garmonsway, The AngloSaxon Chronicle (London: J. M. Dent \& Sons, 1953), pp. xxiv-xxv. The annals are printed in full in The AngloSaxon Chronicle, A Collaborative Edition: Volume 8, MS F, ed. Peter S. Baker (Cambridge: D. S. Brewer, 2000), pp. 129-34.

${ }^{77}$ Religious figures that are named include Archbishop Siric (d. 996), Bishop Ælfric (d. 1005), Saint Ælfheah (d. 1012), Archbishop Lyfing (d. 1020), Deacon Ægelwine (d. 1029), Archbishop Ægelnop (d. 1038), Pope Benedict, Archbishop Stigand, Archbishop Eadsige (d. 1050), Abbot Wulfric (d. 1061), Bishop Godwine (d. 1061), and Lanfranc (archbishop in 1070). Secular leaders that are mentioned include Earls Godwine (d. 1053) and Wælpeof (d. 1076), and Kings Ægelred (d. 1016), Cnut (d. 1035), Harold (d. 1040), Harðacnut (d. 1042), and Edward (d. 1066).

${ }^{78}$ Garmonsway corrects this year to 1072, Garmonsway, Anglo-Saxon Chronicle, p. 271.

${ }^{79}$ Ker, Catalogue, p. 175; The Anglo-Saxon Chronicles, trans. Michael J. Swanton, rev. edn (London: Phoenix, 2000), p. xiv. See also Kato, "London, British Library, Caligula A. xv". On other scribal silences about Conquests, particularly following the succession of King Cnut, see Elaine Treharne, Living through Conquest: the Politics of Early English, 1020-1220 (Oxford: Blackwell, 2012), esp. pp. 48-68.

${ }^{80}$ A facsimile of this folio (135r) is printed in Swanton, Anglo-Saxon Chronicles, pp. xii-xiii.

${ }^{81}$ The Anglo-Saxon Chronicle, A Collaborative Edition: Volume 7, MS E, ed. Susan Irvine (Cambridge: D. S. Brewer, 2004), pp. 90-1. On the entries in the Peterborough Chronicle that were written in Canterbury, see p. lxxxiii. 
${ }^{82}$ Anglo-Saxon Chronicles, trans. Swanton, pp. 210-13.

${ }^{83}$ There may be more to the name of Wælpeof than meets the eye, as this compound name (literally meaning "dead-thief") may be symbolic of his role as a rebel. I would like to thank Michael D. J. Bintley for this suggestion in personal correspondence.

${ }^{84}$ It is also possible that this manuscript could have been written for Stigand, Lanfranc's predecessor, before his deposition as Archbishop of Canterbury in 1070. On the difficulties that Stigand faced during his archiepiscopacy, see Nicholas Brooks, The Early History of the Church of Canterbury: Christ Church from 597 to 1066 (Leicester: Univ. of Leicester Press, 1984), pp. 305-15.

${ }^{85}$ Wælpeof is depicted as a traitor in the Worcester Chronicle (MS D) but Swanton points out that Wælpeof's name in the Peterborough Chronicle "is rubricated as if for the obit of a martyr", Anglo-Saxon Chronicles, trans. Swanton, p. 212.

${ }^{86}$ Florence of Worcester (d. 1118) also presented Wælpeof as a saint and martyr, Florence of Worcester, Florentii Wigorniensis monachi Chronicon ex chronicis, ed. Benjamin Thorpe, 2 vols. (London, 1848-9), II, 12. See also Joanna Huntington, "The Taming of the Laity: Writing Waltheof and Rebellion in the Twelfth Century", Anglo-Norman Studies, 32 (2010), 79-95.

${ }^{87}$ The Claudius Pontificals (from Cotton MS Claudius A. iii in the British Museum), ed. D. H. Turner, HBS, 97 (London: Boydell, 1971), p. v; Ker, Catalogue, p. 176.

${ }^{88}$ These privileges are printed in Heinrich Böhmer, Die Falschungen Erzbischof Lanfranks von Canterbury (Leipzig: Verlag, 1902), pp. 145-61. For a recent discussion of these documents, see Jean Truax, Archbishops Ralph d'Escures, William of Corbeil and Theobald of Bec (Farnham: Ashgate, 2012), pp. 79-81.

${ }^{89}$ Ker, Catalogue, p. 57; The Anglo-Saxon Chronicle, A Collaborative Edition: Volume 3, MS A, ed. Janet Bately (Cambridge: D. S. Brewer, 1986), pp. xiii-xiv. Malcolm Parkes argued that Ælfheah II, Bishop of Winchester, brought the Chronicle to Canterbury in 1006, Malcolm Parkes, "The Palaeography of the Parker Manuscript of the Chronicle, Laws and Sedulius, and Historiography at Winchester in the Late Ninth and Tenth Centuries", ASE, 5 (1976), 171.

${ }^{90}$ Anglo-Saxon Chronicle, ed. Bately, p. xxxix.

${ }^{91}$ Anglo-Saxon Chronicle, ed. Bately, pp. 83-4.

${ }^{92}$ Anglo-Saxon Chronicles, trans. Swanton, pp. 204-6.

${ }^{93}$ See, for example, Bernhard Bischoff and Michael Lapidge, Biblical Commentaries from the Canterbury School of Theodore and Hadrian (Cambridge: Cambridge Univ. Press, 1994), pp. 202-5, 275-96; Hollis, 
“Scientific and Medical Writings", pp. 194-8; Michael Lapidge, The Anglo-Saxon Library (Oxford: Oxford Univ. Press, 2005), pp. 31-3, 275-342; David W. Porter, "Isidore's Etymologiae at the School of Canterbury", ASE, 43 (2014), 7-44.

${ }^{94}$ See notes $20,21,52$, and 73. 